\title{
Semionotiform Fish from the Upper Jurassic of Tendaguru (Tanzania)
}

\author{
Gloria Arratia $^{1}$ \& Hans-Peter Schultze ${ }^{1}$
}

With 12 figures

\begin{abstract}
The late Late Jurassic fishes collected by the Tendaguru expeditions (1909-1913) are represented only by a shark tooth and various specimens of the neopterygian Lepidotes. The Lepidotes is a new species characterized by a combination of features such as the presence of scattered tubercles in cranial bones of adults, smooth ganoid scales, two suborbital bones, one row of infraorbital bones, non-tritoral teeth, hyomandibula with an anteriorly expanded membranous outgrowth, two extrascapular bones, two postcleithra, and the absence of fringing fulcra on all fins.
\end{abstract}

Key words: Fishes, Actinopterygii, Semionotiformes, Late Jurassic, East-Africa.

\section{Zusammenfassung}

Die spätoberjurassischen Fische, die die Tendaguru-Expedition zwischen 1909 und 1913 gesammelt hat, sind durch einen Haizahn und mehrere Exemplare des Neopterygiers Lepidotes repräsentiert. Eine neue Art der Gattung Lepidotes ist beschrieben, sie ist durch eine Kombination von Merkmalen (vereinzelte Tuberkel auf den Schädelknochen adulter Tiere, glatte Ganoidschuppen, zwei Suborbitalia, eine Reihe von Infraorbitalia, nichttritoriale Zähne, Hyomandibulare mit einer membranösen nach vorne gerichteten Verbreiterung, zwei Extrascapularia, zwei Postcleithra und ohne sich gabelnde Fulkren auf dem Vorderrand der Flossen) gekennzeichnet.

Schlüsselwörter: Fische, Actinopterygii, Semionotiformes, Oberer Jura, Ostafrika.

\section{Introduction}

At the excavations of the Tendaguru expeditions (1909-1913), fish remains were collected together with the spectacular reptiles in sediments assigned to the late Late Jurassic, probably the Tithonian (Fig. 1; for detailed information on the locality and geological setting see Heinrich, this volume).

Hennig (1914: pl. 23, figs 1, 2) provided the first general description of the fishes and identified them as Lepidotus minor in the text and as Lepidotus aff. minor in the explanation of the plate. In addition to Lepidotus (= Lepidotes), one elasmobranch tooth was found and assigned to Orthacodus sp. (probably a hybodont tooth; thin section MB. Hi.4). The identification of the Tendaguru lepidotid material to Lepidotes minor Agassiz (originally described from the Purbeckian of Dorsetshire, England) was based on the tuberculation of the skull bones, on the structure of the scales (smooth surface, straight posterior margin, crescent shaped lateral line pore, and the number of scales in vertical and longitudinal rows), and on the shape of teeth (non-tritoral). However, the Tendaguru lepidotid differs notably from $L$. minor in the size of the postparietal (= parietal) bone, the number of circumorbital bones, the structure of the dorsal ridge scales, and other features (see below).

The genus Lepidotes Agassiz, 1832 is a Mesozoic taxon that ranges from the Triassic through the Late Cretaceous. Lepidotes had an almost cosmopolitan distribution. Nevertheless, most species have been described from the Jurassic and Cretaceous of Europe (e.g., Agassiz 1832, 1833-44, Quenstedt 1847, Wagner 1863, Branco 1887, Sauvage 1893, Woodward 1895, Priem 1908, Dechaseaux 1943, Jain \& Robinson 1963, Malzahn 1963, Wenz 1968, Jain 1985, Thies \& Zapp 1997). A few species are reported from other continents (e.g., Egerton 1878, Mann \& Hennig 1913, Silva Santos 1953, Bocchino 1973, Jain 1983, Thies 1989a, Arratia \& Cione 1996, Chang \& Jin 1996).

\footnotetext{
1 Museum für Naturkunde, Institut für Paläontologie, Invalidenstr. 43, D-10115 Berlin, Germany. Received March 1999, accepted June 1999
} 
With few exceptions, most species of Lepidotes are poorly known. Consequently, all attempts to characterize the genus are insufficient (see Branco 1887, Woodward 1895, 1919, Jain 1983, McCune 1986, Thies 1989a). A world-wide revision of the species included in the genus is needed in order to provide unambiguous synapomorphies for the genus and to define its composition. The present description, based on material deposited in the Museum für Naturkunde in Berlin, provides some new insights in the understanding of the semionotiforms and their diversity.

\section{Material and methods}

The Lepidotes specimens were discovered in two separate localities (Fig. 1): two specimens in red ironstone concretions $700 \mathrm{~m}$ north of Tendaguru Hill in Trench XIIa (Fig. 2A, B) and many specimens and parts of specimens (Fig. 3B) packed above each other in grey sandstone $250 \mathrm{~m}$ south of Tendaguru Hill at locality $M$ together with the sacrum of Dicraeosaurus sattleri. Hennig (1914) cited additional single scales from different localities in the Tendaguru area.

The concretions were opened in the Museum für Naturkunde, Berlin (Hennig 1914). One of these is the holotype. Some of the specimens in a grey sandstone (Hennig 1914) were brought to Berlin. They were only marginally used in the description by Hennig (1914). Many of the important characters of the new species were discovered in this material after needle preparation.

The material has been examined and drawn under a Wild MZ8 dissecting microscope with drawing attachment. The SEM pictures of the ganoin surface have been taken with a SEM Jeol 6300.

Abbreviation: MB. = collections of the Institut für Paläontologie, Museum für Naturkunde, Humboldt-Universität zu Berlin.

Terminology: Some of the terminology of actinopterygian dermal cranial bones implying homology with other osteichthyans is unsatisfactory. A combined terminology is sometimes used, e.g., actinopterygian frontal and parietal together with tetrapod jugal (e.g., Long 1988, Gardiner \& Schaeffer 1989). Few authors have addressed the question of homology of certain head bones across major osteichthyan groups (e.g., Romer 1945, Jollie 1962, Borgen 1983, Schultze \& Arsenault 1985, Arratia \& Schultze 1990, 1991, Schultze 1993, Arratia \& Cloutier 1996). According to homologization of dermal skull bones in osteichthyans, we identify the so-called frontal in actinopterygians as the parietal and the so-called parietal as the postparietal throughout this paper. This is of extreme importance; it reveals that other bones in actinopterygians like the dermopterotic for example could correspond to the dermosphenotic or to the supratemporal in other osteichthyans, or it could be a new element at certain level of the phylogeny of osteichthyan fishes; however, the homology of this bone has never been studied, as well as that of the epiotic and extrascapula, just to give a few examples.

During this study we encountered a specific problem with the names of the circumorbital series. In actinopterygians a series of commonly small, slightly rectangular or squareshaped bones surround the orbit. These bones are the supraorbitals, the dermosphenotic, the infraorbitals, and the antorbital(s). As their names suggest, the supraorbitals frame the dorsal margin of the orbit; the dermosphenotic is between the last or most posterior supraorbital and the last or most dorsoposterior infraorbital; the infraorbitals frame the ventral and posterior margin of the orbit; and the antorbital is placed anterior to the first infraorbital and commonly extends anteriorly and/or dorsally. It may close the orbit anteriorly or it may not. A series of bones is present in front of the orbit in Lepidotes and Semionotus. Commonly, these bones are not labeled in previous figures of Lepidotes and Semionotus (e.g., Quenstedt 1847: pl. 1, figs 1, 3, Lehman 1966: fig. 156, Jain \& Robinson 1963: figs 2, 3, Jain 1983: fig. 3). Wenz (1968: fig. 40), Thies (1989b: fig. 2), and Thies \& Zapp (1997: fig. 7) identified them as infraobitals in Lepidotes despite the fact that in front of the orbit in other actinopterygians infraorbital bones are not known, but that is the position of the antorbital. In contrast, Jain (1983) identified them as antorbitals and used the number of these elements as one feature to separate Acentrophorus (1), Semionotus ( 1 or 2 ), and Lepidotes (usually 3 ). A bone in a similar position was named as antorbital in Acentrophorus and in Semionotus by Gardiner (1960: figs 70, 71). Olsen \& McCune (1991: 275) named these bones in Semionotus as "lacrimals" following Wiley's (1976) interpretations of lepisosteids, and stated that this nomenclature is ... "a convention followed by us without implying specific homology with the lacrimal of primitive osteichthyans". This argument is difficult to understand because the bone commonly identified as lacrimal in actinopterygians is the infraorbital 1 and is a single bone. In the semionotiform Dapedium there is a single bone in front of the orbit identified as antorbital (e.g., Gardiner 1960, Thies 1988). Because the new fish described here has an incomplete circumorbital series and shows a peculiar series of bones in front of the orbit we cannot make a decision about the homology of these bones. Therefore, we leave the problem pending a broad revision of circumorbital bones in actinopterygians.

\section{Systematic paleontology}

Division Halecostomi Regan, 1923

Order Semionotiformes Arambourg \& Bertin, 1958 Family Semionotidae Woodward, 1890 pro parte Genus Lepidotes Agassiz, 1832

The fishes studied herein are considered Lepidotes following the revised diagnoses by Jain (1983: 37) and Thies (1989a: 19) and by a comparison with other species of the genus. For instance, they share the presence of more than one suborbital bone and a dentalosplenial with a long posterior process almost reaching the posterior border of the mandible. Unfortunately, some of the diagnostic characters cannot be checked in the material, e.g. whether the vomer is a single or paired element, and whether two pockets are present on the inner side of the epiotic. According to Jain and Thies, the genus Lepidotes is also characterized by the presence of inconspicuous dorsal ridge scales without a posterior spine. However, dorsal ridge scales with a posterior spine similar to those of Semionotus are at least found in Lepidotes deccanensis, L. minor, L. maximus, and L. mantelli (Woodward 1895, 1919, Weitzel 1930, Jain 1983). Considering the above information as presently un- 


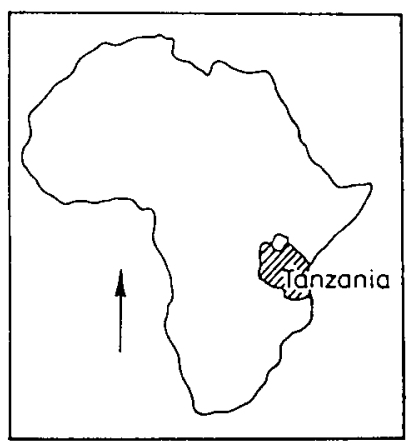

\section{Geographic location and geological structure of Tendaguru, Tanzania}
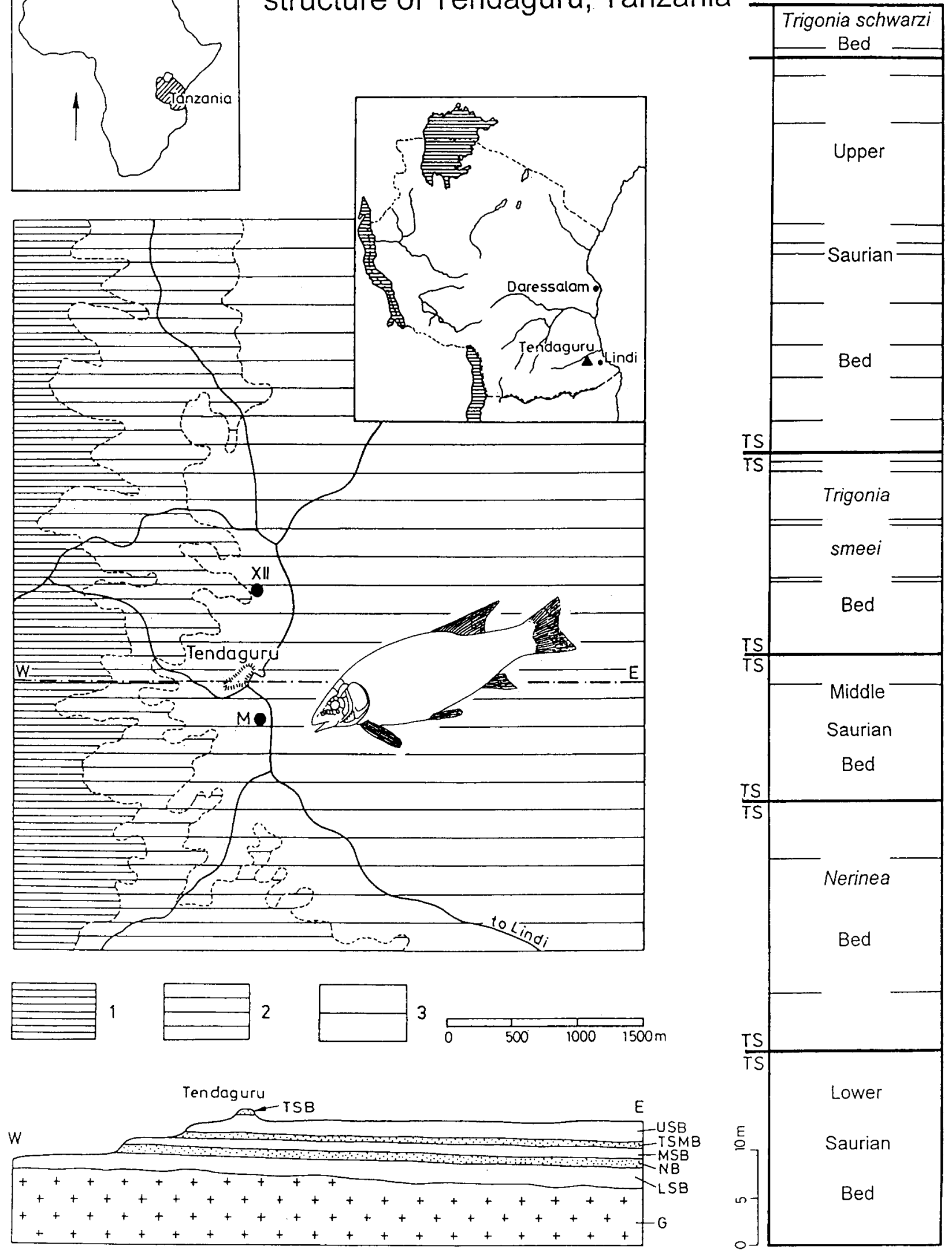

Fig. 1. Map of the Tendaguru area with geological sections and the localities (XII and M) considered in the present account (after Heinrich, this volume). 1, Lower Saurian Bed; 2, Middle Saurian Bed; 3, Upper Saurian Bed; TSB, Trigonia schwarzi Bed; USB, Upper Saurian Bed; TSMB, Trigonia smeei Bed; MSB, Middle Saurian Bed; NB, Nerinea Bed; LSB, Lower Saurian Bed; G, gneiss; TS, Transitional Sands 
derstood, members of the genus Lepidotes may have both conditions: Dorsal ridge scales with or without a posterior spine.

Type-species: Lepidotes elvensis (Blainville 1818) from the Upper Lias of England, France, and Germany.

\section{Lepidotes tendaguruensis n. sp.}

Figs 2-12

Synonyms:

1914 Lepidotus minor AG. - Hennig: 296-303, figs 1-4.

1914 Lepidotus cf. minor AG. - Hennig: pl. 23, figs 1, 3.

Holotype: MB. f.7040a-b; posterior part of head, body lacking the tail; incomplete fins (Figs 2A, 5A, 6A, Hennig 1914: pl. 25, fig. 1).

Paratypes: MB. f.7041a-b, posterior part of head, body lacking the tail; incomplete fins (Figs 2B, 5B, 6B); MB. f.7042 (Fig. 4A), posterior part of head, body missing the caudal rays; MB. f.7043 (Figs 4B, 9C), MB. f.7044 (Fig. 7A), MB. f.7045 (Fig. 8), MB. f.7046 (Fig. 7B), and MB. f.7047, several incomplete and disarticulated juvenile and large specimens; MB. f.7048, incomplete, juvenile specimen missing tail (Fig. 9A, B); MB. f.7049, scales (Hennig 1914: fig. 1); MB. f.7050, head bones; MB. f.7051, disarticulated head bones; MB. f.7052, disarticulated head bones; MB. Hi.1, vertical section of tooth (Hennig 1914: fig. 4); MB. Hi.2 (Hennig 1914: pl. 23, fig. 3) and Hi. 3, vertical sections of scales.

Additional specimens: MB. f.7053, disarticulated head bones and scales; MB. f.7054, incomplete head bones and squamation.

Diagnosis (based on a combination of features most of which are autapomorphies [*]): Semionotiform with skull roof bones and orbital series covered with scattered tubercles in large individuals. Flat, broad posterior process of epiotic ending in few tooth-like dentations [*]. Two suborbital bones; dorsal suborbital small and slightly rectangular or ovoid; ventral suborbital dorsoventrally elongated. Infraorbital at posteroventral corner of orbit slightly expanded ventroposteriorly [*]. Anterior infraorbital bones or antorbitals, rectangular shaped and placed above each other [*]. Relatively small teeth with rounded crowns on dentalosplenial and premaxilla. Inner rows of dentalosplenial teeth nontritoral. Preoperculum not reaching the lateral border of dermopterotic [*]. Hyomandibula with a well developed anterior membranous outgrowth [*]. Two postcleithra [*]. Dorsal ridge scales lacking a posterior spine. Fringing fulcra and basal scutes absent [*].

Type-locality: Trench XIIa approximately $700 \mathrm{~m}$ north of Tendaguru Hill (red ironstone concretions MB. f.7040, MB. f.7041, and MB. Hi.3), and locality $M$, approximately $250 \mathrm{~m}$ south of Tendaguru Hill (MB. f.7042-f.7050 and blocks with scales in grey sandstone, MB. Hi.1-2). All from Tendaguru, Tanzania (Fig. 1).

Type-horizon: Obere Sauriermergel, Tithonian, Upper Jurassic.

Derivatio nominis: Named after Tendaguru, the type locality.

Description: Fishes of approximately $250 \mathrm{~mm}$ maximum known total length. The dorsal margin of the body is quite elevated behind the head (Fig. 2A, B); therefore, the deepest part of the body is between head and dorsal fin; the depth of the body decreases strongly posteriorly. In contrast, the body is elongated (Fig. 3A) in juvenile specimens, lacking the strong dorsal profile which is acquired during growth. The depth of the caudal peduncle is one third of the maximum depth of the body. The pectoral fins are placed down on the flanks. The dorsal fin lies opposite to the pelvic fins. There are no significant differences in size and shape of the scales on the body except for small, slightly oval scales found at the base of the dorsal and anal fin-rays. There are more than 19 scales in a vertical row posterior to the head, circa 21 scales (similar number as given by Hennig in 1914) at the middle region between posterior part of head and origin of dorsal fin, and about 14 scales just posterior to the last dorsal fin-ray (MB. f.7040b). Juvenile specimens lack ornamentation on head bones; however, some of them show the appearance of a few small tubercles on parietal or postparietal bones. In contrast, large specimens have tubercles of different sizes on the skull roof and orbital bones (Figs 2A, 6B). Bones of the skull roof that we could identify in the studied material, include the parietals (= frontals), sphenotics, postparietals (= parietals), dermopterotics, epiotics, extrascapulars, and posttemporals.

Bones of the snout, such as the rostral, nasals, and ethmoidal elements are not described due to lack of adequate preservation.

The posterior part of the thick parietal (= frontal) bone (Figs 4, 5A, 6A, B, 7A, B) is usually preserved; however, MB. f.7043 (Fig. 5B), MB. f.7048, and MB. f.7050 show also the anterior part. The bone is narrow and elongated anteriorly, it expands posteriorly and it is markedly inclined anteroventrally. The suture between left and right bones is almost straight. The parietal sutures posterolaterally with the sphenotic and the dermopterotic. The parietal sutures posteriorly with the postparietal. The sphenotic is incompletely preserved, it is a massive bone. All sutures between these bones are straight. 
The supraorbital canal (Fig. 4) runs enclosed in a tube inside the parietal and postparietal and exits to the surface by a series of pores that are placed laterally to the canal. The number of pores increases during growth. For instance, young specimens have three to five pores in the posterior part of the bone, but large specimens have 14 or more pores (Figs 4, 7A). A series of small pits, ordered in a row are interpreted here as pits for neuromasts producing a neuromast line or pit-line. Such lines are observed in the parietal bone and also in the postparietal.

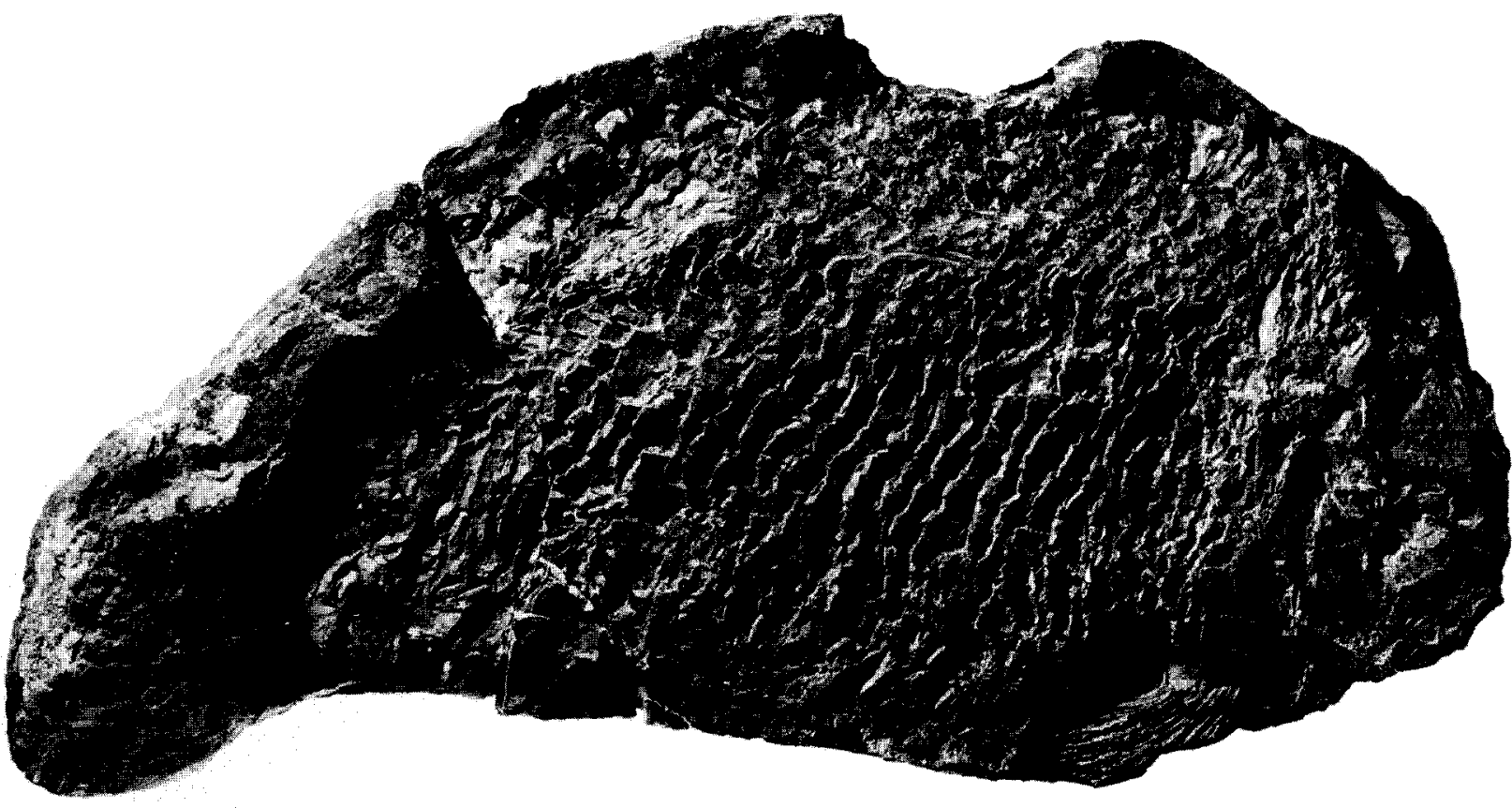

A

$3 \mathrm{~cm}$

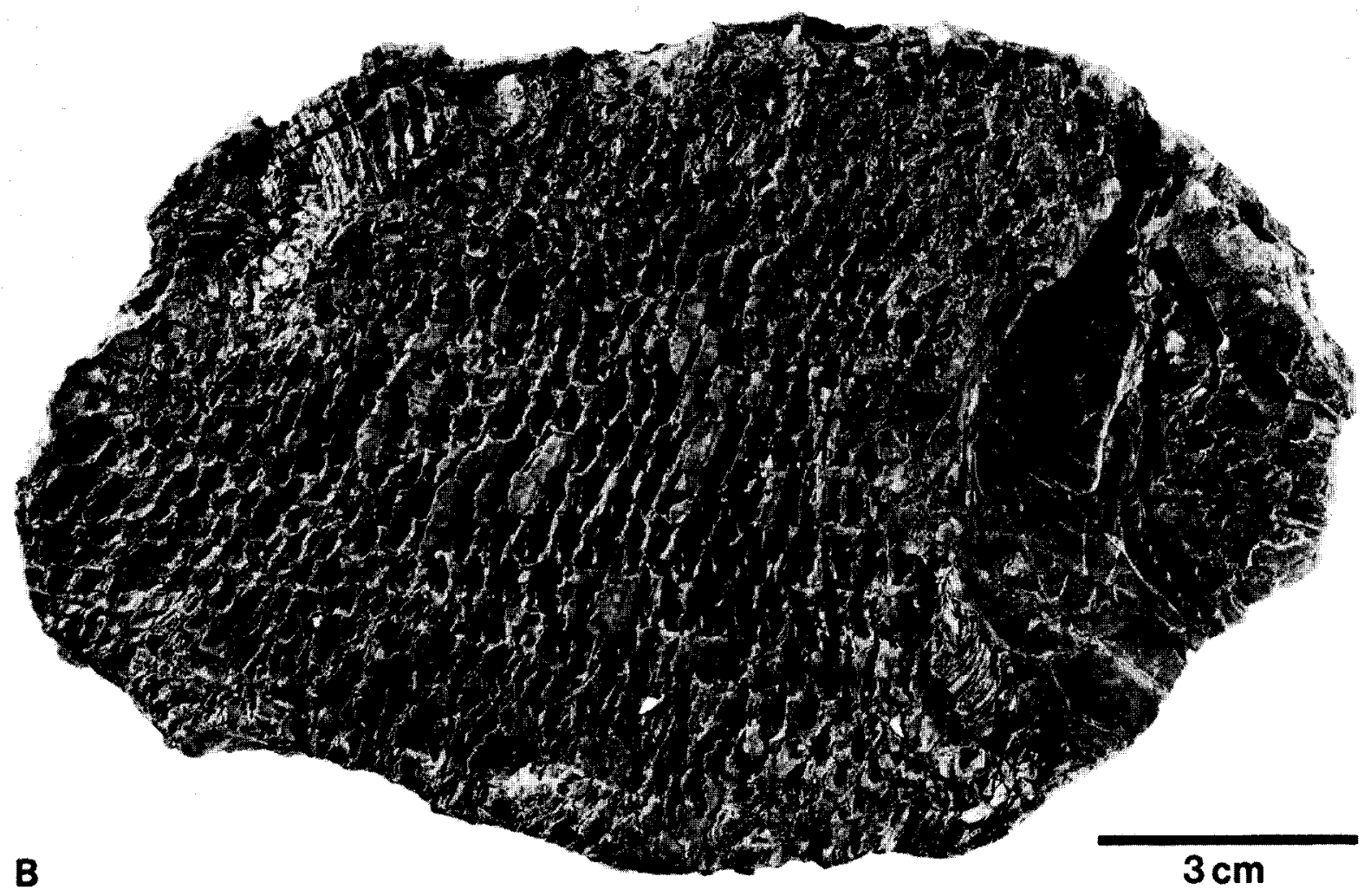

Fig. 2. Lepidotes tendaguruensis n. sp. A. MB. f.7040b, holotype. B. MB. f.7041a, paratype. Obere Sauriermergel, Tithonian, Upper Jurassic/Trench XIIa approximately $700 \mathrm{~m}$ north of Tendaguru Hill, Tendaguru, Tanzania 

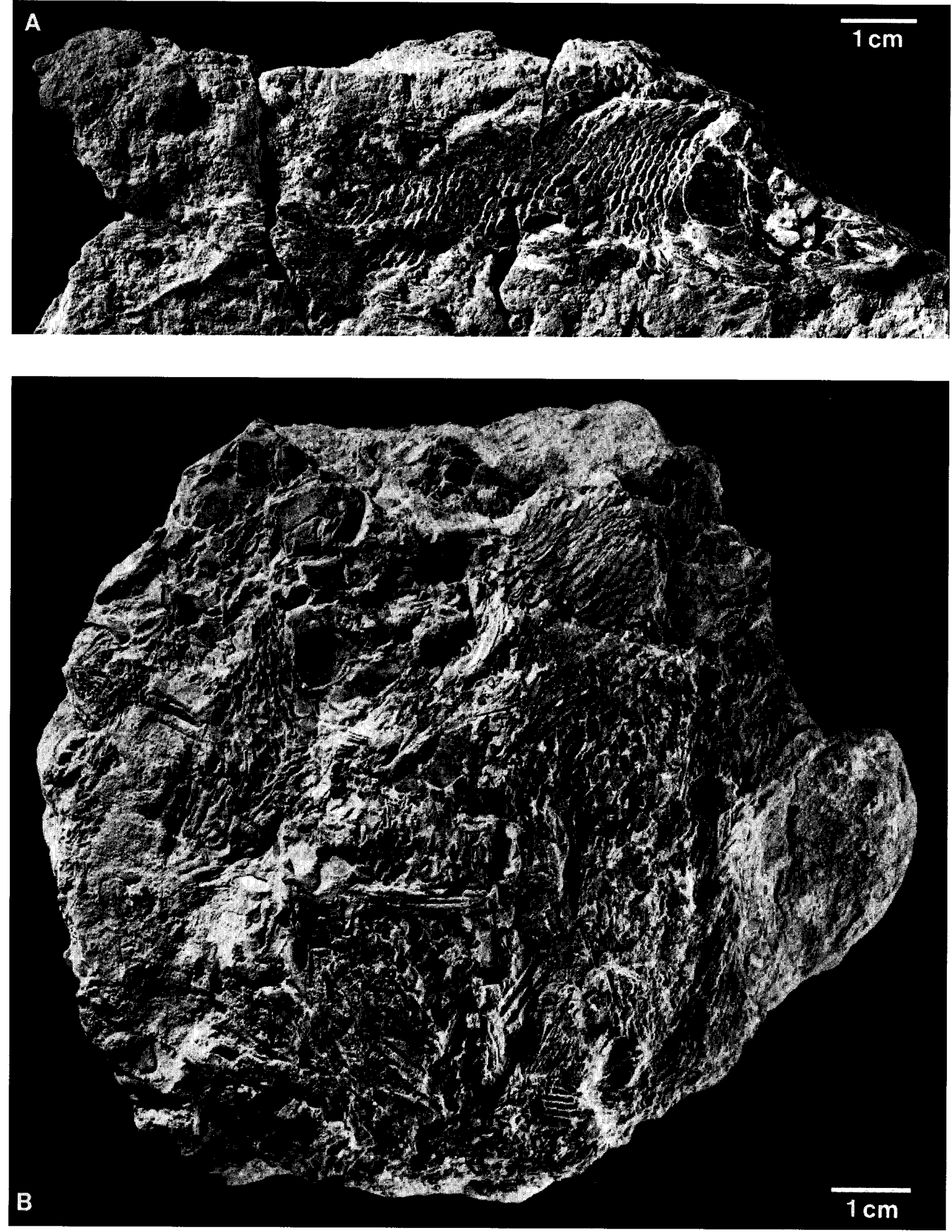

Fig. 3. Lepidotes tendaguruensis n. sp. A. MB. f.7043, nearly complete specimen. B. MB. f.7046, above each other packed specimens. Obere Sauriermergel, Tithonian, Upper Jurassic/Locality M, approximately $250 \mathrm{~m}$ south of Tendaguru Hill, Tendaguru, Tanzania 
The dermopterotic (Figs 4, 7B, 8A, B) forms the posterolateral border of the skull roof. It is strongly ossified and presents two or three pores of the otic canal closer to its lateral margin. A short groove for the middle pit-line has been observed in two specimens.

The postparietal (= parietal) (Figs 4, 5A, B, $7 \mathrm{~A}, \mathrm{~B}, 8 \mathrm{~B})$ is a thick, heavily ossified bone almost square in shape and as long as wide. Its length is about one quarter of the parietal length. The supraorbital canal enters the postparietal closer to the lateral margin than to the medial margin as in other Lepidotes species (e.g., L. laevis: Saint-Seine 1949; L. gloriae: Thies 1989a). The number of pores is variable from specimen to specimen (e.g., none to three) like in the parietal bone. The pit-lines show variability also. Some specimens have a middle pit-line, others have a pit-line that runs parallel to the supraorbital canal, and other do not have any pit-lines. The supratemporal commissure does not run through the postparietal as it does in L. gloriae (Thies 1989a: fig. 7).

The postparietal sutures posteriorly with the epiotic. The epiotic (Fig. 8A) has two regions: an anterior one (subtriangular in shape) formed by endochondral bone, and a posterior elongated one of endochondral bone overlapped by a thick, slightly ovoidal ossification which extends caudad, and ends in two or three sharp, flat points, that look like a dentate border.

The extrascapula (Fig. 5B) is L-shaped. Its anterolateral portion lies against the dermopterotic, whereas the bone curves posteriorly and extends medially. The size of the bone indicates that the fish has only two extrascapular bones like Lepidotes elvensis, L. deccanensis, L. leedsi, and L. notopterus (e.g., Wenz 1968, Jain 1983).

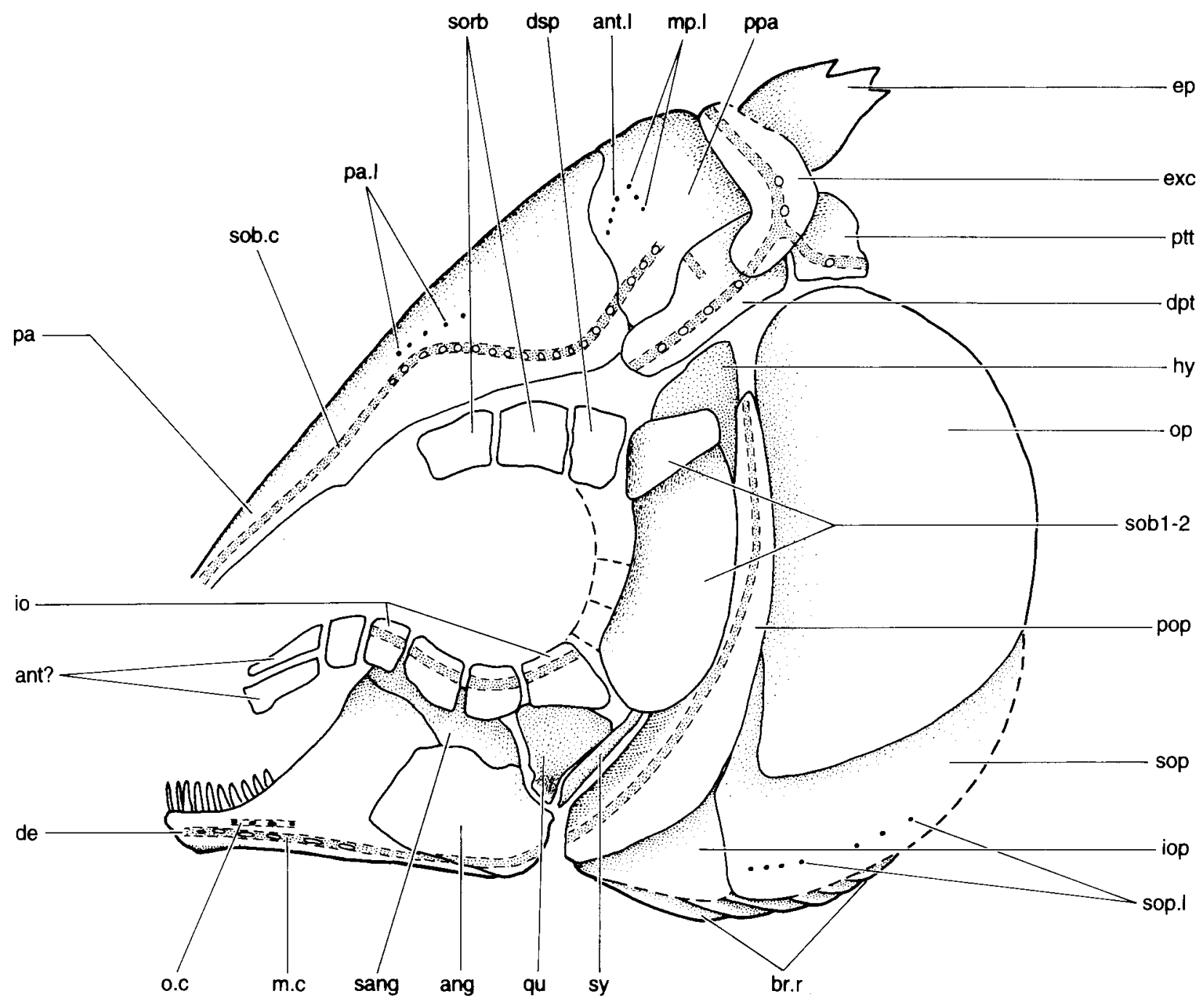

Fig. 4. Lepidotes tendaguruensis n. sp. Restoration of the head in lateral view. ang, angular; ant?, antorbital?; br.r, branchiostegal ray; de, dentalosplenial; dpt, dermopterotic; ep, epiotic; exc, extrascapula; hy, hyomandibula; io, infraorbital bone; iop, interoperculum; m.c, mandibular canal; o.c, oral canal; op, operculum; pa, parietal (= frontal); pop, preoperculum; ppa, postparietal (= parietal); ptt, posttemporal; qu, quadrate; sob, suborbital bone; sob.c, supraorbital canal; sop, suboperculum; sop.l, subopercular line; sy, symplectic 


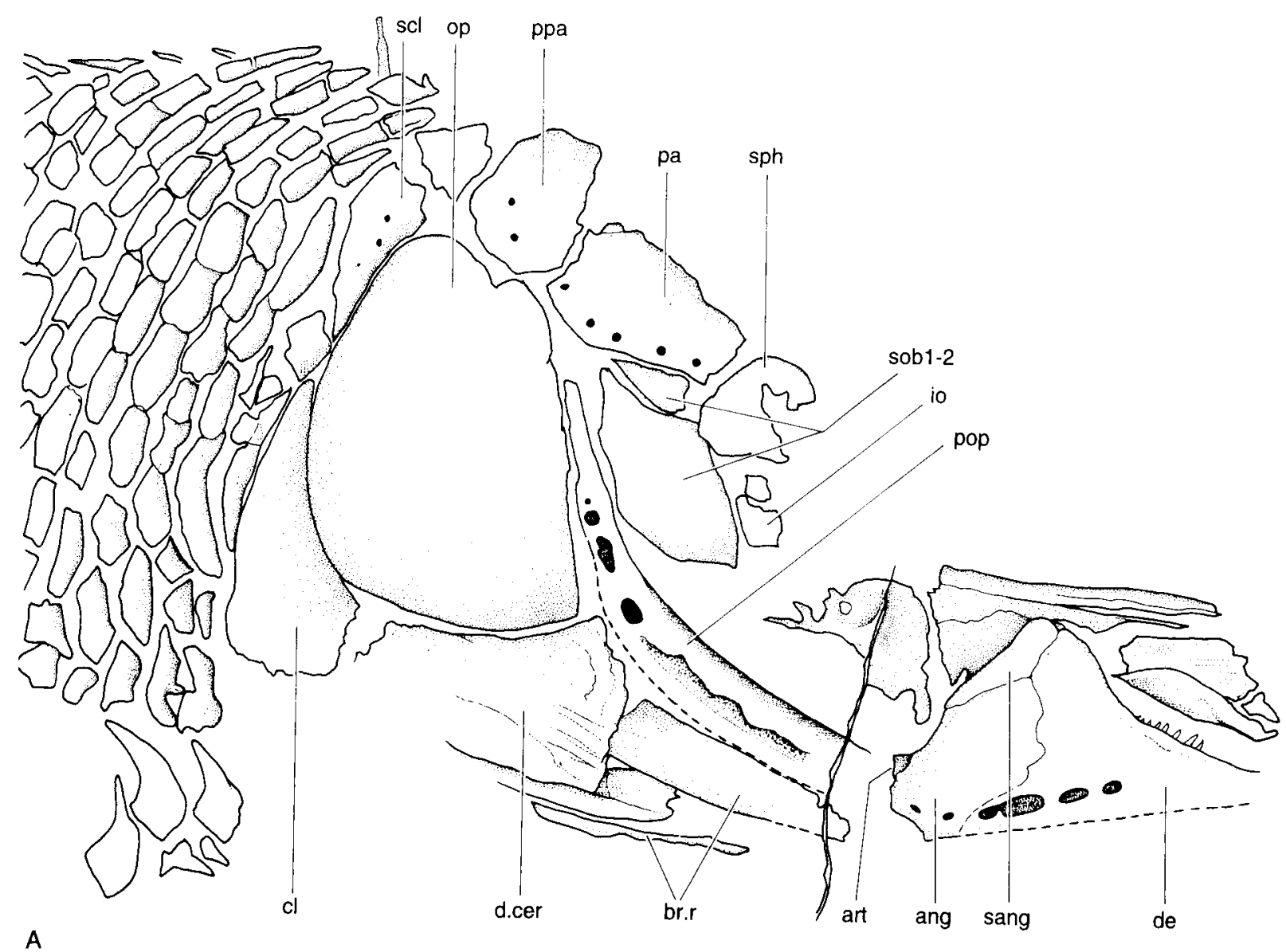

A

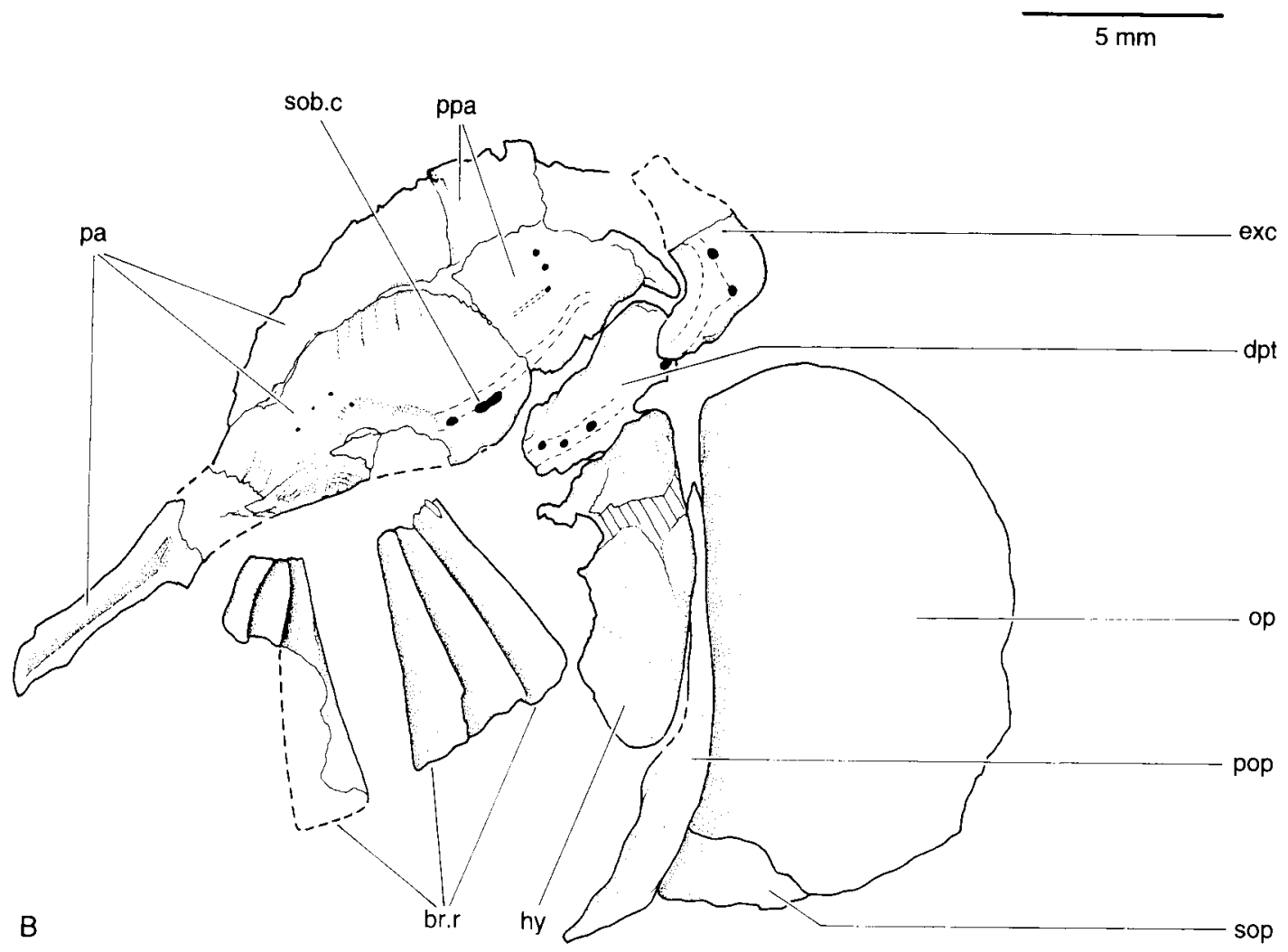

Fig. 5. Lepidotes tendaguruensis n. sp. A. Posterior part of head and part of body (MB. f.7043). B. Skull roofing bones and other head bones (MB. f.7047). Obere Sauriermergel, Tithonian, Upper Jurassic/Locality M, approximately $250 \mathrm{~m}$ south of Tendaguru Hill, Tendaguru, Tanzania. A and B same scale. ang, angular; art, articular; br.r, branchiostegal ray; cl, cleithrum; d.cer, displaced anterior ceratohyal; de, dentalosplenial; dpt, dermopterotic; exc, extrascapula; hy, hyomandibula; io, infraorbital bone; op, operculum; pa, parietal (= frontal); pop, preoperculum; ppa, postparietal (= parietal); sang, surangular; scl, supracleithrum; sob.c, supraorbital canal; sob1-2, suborbital 1-2; sop, suboperculum; sph, sphenotic 
The posttemporal (Fig. 8A) does not show an anterior elongated process. The main body of the bone is slightly squarish and ventroposteriorly it presents a small articular surface for the anterior margin of the supracleithrum. At least one sensory pore has been observed on the posttemporal.

The parasphenoid is preserved as a disarticulated element. It narrows below the anterior part of the orbit and even more further anteriorly (Fig. 9). Its width increases posteriorly to reach a maximum at the basipterygoid process. The socalled ascending process, a long process in Pholidophorus and Leptolepis, is here very short. The posterior ascending lamina extends posterioly to occupy half the length of the posterior part of the parasphenoid. The parasphenoid is forked posteriorly presumably to form the aortic notch. The dorsal opening of the bucco-hypophysial ca- nal lies between the two basipterygoid processes. The foramen for the efferent pseudobranchial artery as well as foramina for nerves have not been observed.

The circumorbital series (Figs 4, 7A, B) is incomplete in all specimens examined. It comprises supraorbital, antorbital?, infraorbital, and suborbital bones. One sclerotic bone is preserved in one specimen. Supra- and infraorbital bones are small elements surrounding the orbit in a single row. The orbit, according to our restoration, is moderately large. At least two slightly rectangular or squarish supraorbitals, a squarish dermosphenotic, at least two bones at the posterior margin of the orbit and seven ventral infraorbitals (including the possible antorbitals) are preserved in the holotype. The infraorbital at the posteroventral corner of the orbit is larger than the other infraorbitals, it expands posteroven-
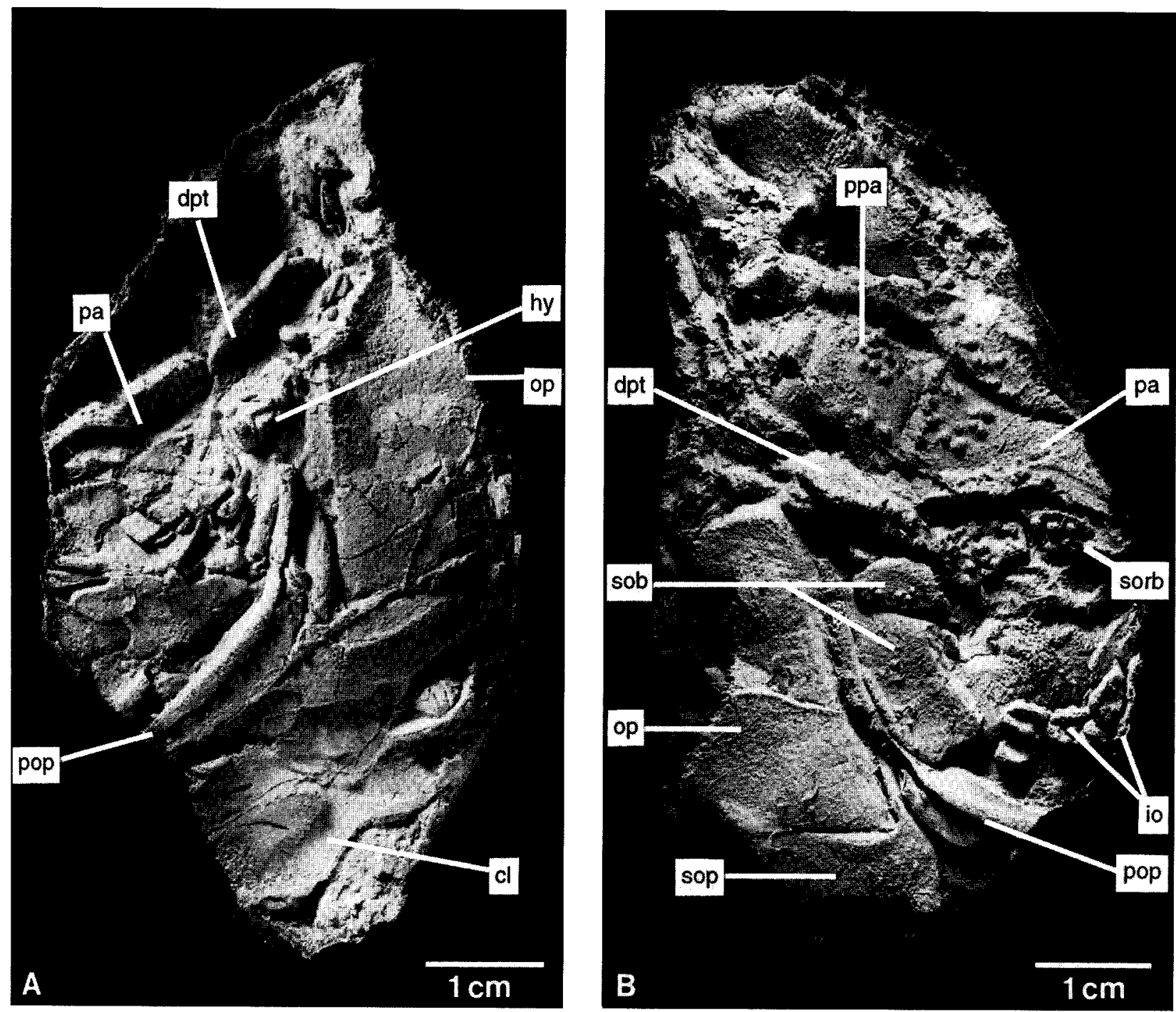

Fig. 6. Lepidotes tendaguruensis n. sp. Head bones in lateral views. A. Cast of MB. f.7041a coated with $\mathrm{NH}_{4} \mathrm{Cl}$. B. Cast of $\mathrm{MB}$. f.7040a coated with $\mathrm{NH}_{4} \mathrm{Cl}$. Obere Sauriermergel, Tithonian, Upper Jurassic/Trench XIIa approximately $700 \mathrm{~m}$ north of Tendaguru Hill, Tendaguru, Tanzania. For anatomical abbreviations see Fig. 7 
trally. The most characteristic elements are the two suborbital bones that cover the area between the infraorbitals and the preoperculum. Suborbital 1 is a small, slightly oval or rectangular, heavily ossified bone. Suborbital 2 is a large bone covering most of the posterior part of the cheek. There are preserved four infraorbital or antorbital bones in front of the orbit. Anterior infraorbitals (or antorbitals) 3 and 4 have similar shape, size and ornamentation as the following infraorbitals; however, anterior infraorbitals 1 and 2 (or antorbitals?) are elongated bones placed one above the other forming the anterior part of the circumorbital series, and it is unclear whether they are infraorbital or antorbital bones.

The upper jaw (Fig. 10C) is poorly preserved and includes premaxilla and maxilla. We cannot establish whether a supramaxilla was present or not because of poor preservation. The premaxilla is a large, slightly ovoid bone that strongly projects posterodorsally. A row of small teeth has been observed in one specimen. The maxilla is incompletely preserved in all specimens, and it apparently expands posteriorly.

The lower jaw (Figs 4, 5A, 10A, C) comprises the dentalosplenial, surangular, and angular in

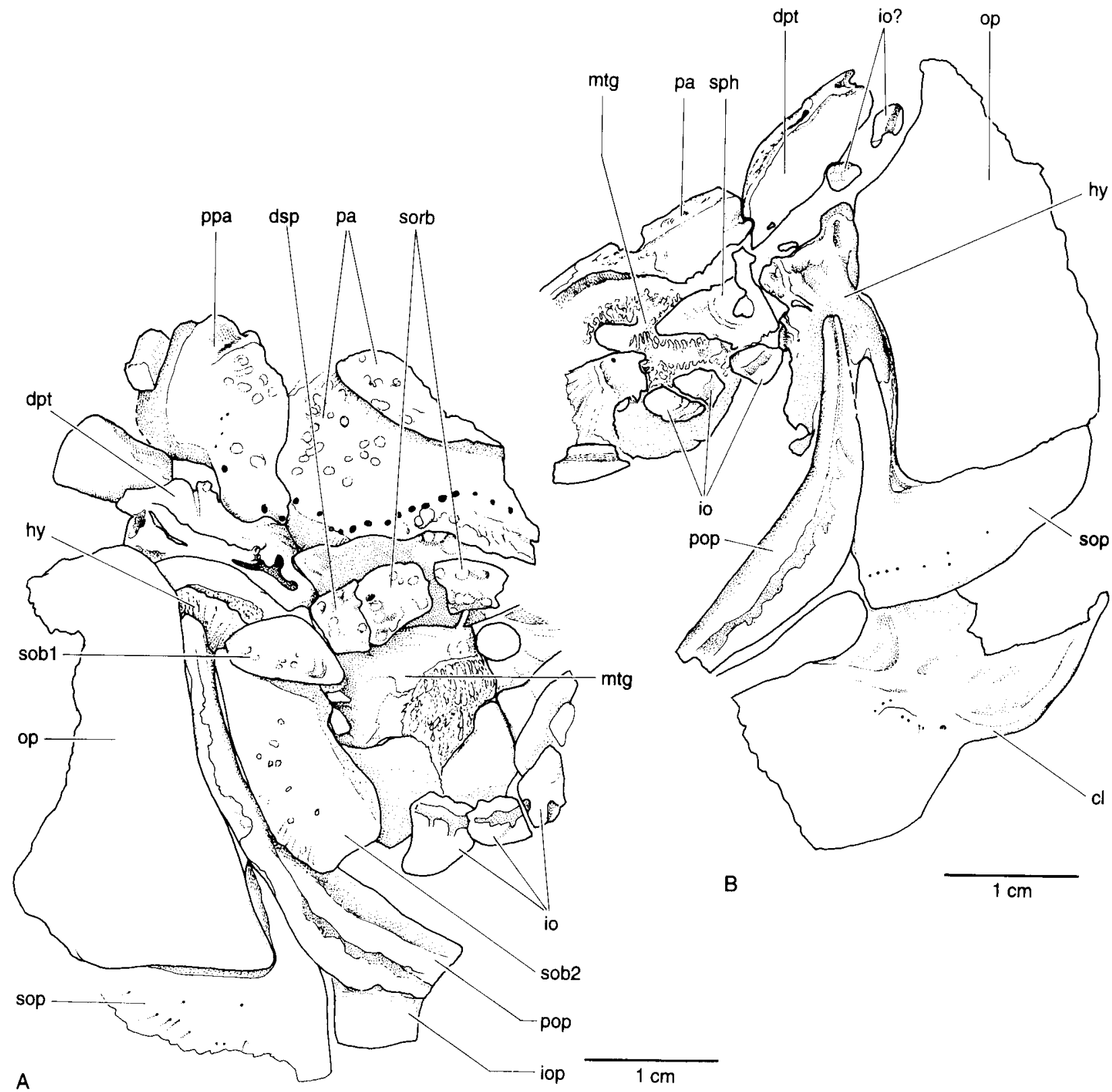

Fig. 7. Lepidotes tendaguruensis n. sp. Head bones in lateral views. A. Based on cast of MB. f.7040a. B. Based on cast of MB. f.7041a. Obere Sauriermergel, Tithonian, Upper Jurassic/Trench XIIa approximately $700 \mathrm{~m}$ north of Tendaguru Hill, Tendaguru, Tanzania. cl, cleithrum; dpt, dermopterotic; dsp, dermosphenotic; hy, hyomandibula; io, infraorbital bone; iop, interoperculum; mtg, metapterygoid; op, operculum; pa, parietal; pop, preoperculum; ppa, postparietal; sob1-2, suborbital bone 1-2; sop, suboperculum; sorb, supraorbital bone; sph, sphenotic 
lateral view. The inner composition of the lower jaw is unknown, but a piece of the articular is preserved in one specimen. The jaw is very narrow at the level of the symphysis, its dorsal margin ascends abruptly posteriorly. The dentalosplenial forms a deep coronoid process together with the surangular. The slender anterior part of the dentalosplenial with a shallow symphysis produces ventrally a small, broad process or chin like in many other species of the genus. The posteroventral process of the dentalosplenial projects caudally, almost reaching the posterior border of the angular. The teeth of the dentalosplenial do not show differences in shape between the external and internal rows; they are small with almost round crowns (Fig. 9B) formed by acrodin (the clear dorsal tip in Hennig 1914: fig. 4). No tritoral teeth have been observed as- sociated with the jaws or with any other bone; therefore the species is considered non-tritoral like Lepidotes elvensis and L. deccanensis. The surangular is a large bone forming the posterodorsal region of the jaw.

Two series of sensory pores (Figs 4, 10C) are preserved in the dentalosplenial as in Lepidotes gloriae and L. elvensis (Thies 1989a, b). The dorsal series belongs to the oral canal, it has few small, rounded or oval pores. The ventral series corresponds to the mandibular canal, it has large pores that become confluent, producing a large aperture in some specimens.

The lower jaw articulates with the quadrate and the symplectic (Fig. 10C). The quadrate is a small triangular bone forming a well developed articular condyle and a small triangular body that contacts the ectopterygoid and the meta-

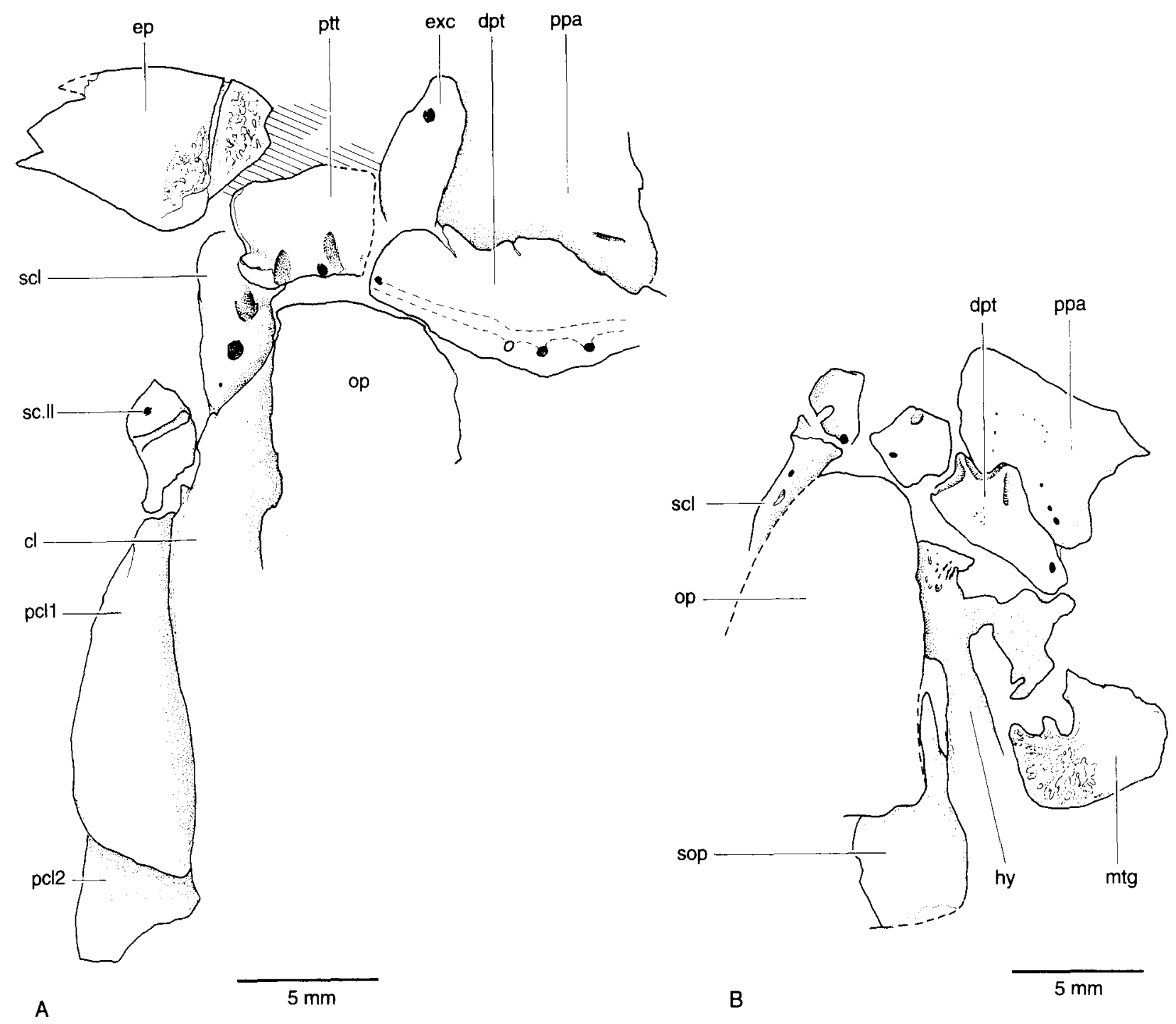

Fig. 8. Lepidotes tendaguruensis n. sp. Head bones in lateral view. A. MB. f.7044. B. MB. f.7046. Obere Sauriermergel, Tithonian, Upper Jurassic/Locality M, approximately $250 \mathrm{~m}$ south of Tendaguru Hill, Tendaguru, Tanzania. cl, cleithrum; dpt, dermopterotic; ep, epiotic; exc, extrascapula; hy, hyomandibula; mtg, metapterygoid; op, operculum; pcl1-2, postcleithrum 1-2; ppa, postparietal; ptt, posttemporal; scl, supracleithrum; sc.ll, scale carrying the lateral line; sop, suboperculum 


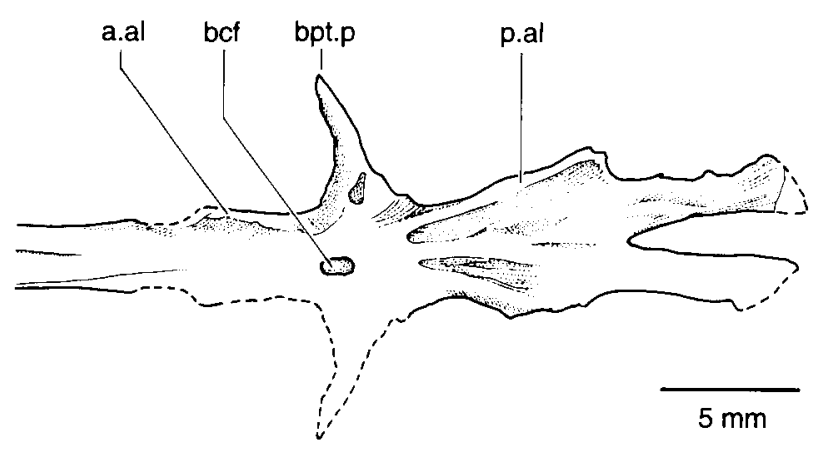

Fig. 9. Lepidotes tendaguruensis n. sp. Parasphenoid in dorsal view (MB. f.7045). Obere Sauriermergel, Tithonian, Upper Jurassic/Locality M, approximately $250 \mathrm{~m}$ south of Tendaguru Hill, Tendaguru, Tanzania. a.al, anterior ascending lamina; bef, bucco-hypophysial opening; bpt.p, basipterygoid process; p.al, posterior ascending lamina

pterygoid. A process at the posterior border of the quadrate is absent. A long symplectic lies posterior to the quadrate. The metapterygoid (Fig. 8B) is enlarged as well as the symplectic to connect the ventral and dorsal portions of the suspensorium; they compensate the small quadrate and the moderately long hyomandibula.

The hyomandibula is a broad bone with an expanded anterior membranous outgrowth. The bone is unusual in the presence of an articular surface in the dorsal part of the outgrowth (Fig. 7A, B) which could be an accessory articulation with the basipterygoid process. We cannot verify the relations and function of this process, because the bones of the braincase are not preserved. The bone has one elongated articulation with the neurocranium in numerous specimens. Specimen MB. f.7041 (Fig. 7B) shows that the dorsal articular region of the hyomandibula has two articular condyles, one directed anteriorly and the other posteriorly. Both processes are connected by a thin bony lamina. The opercular process has not been observed because it is covered by the operculum.

The large, slightly square-shaped metapterygoid is a flat bone still retaining a considerable quantity of cartilage or calcified cartilage. Remains of the ecto- and endopterygoid have been observed. It is unclear whether the ectopterygoid bears teeth or not.

The hyoid arch is incompletely preserved. Only a portion of the anterior ceratohyal is preserved and a few moderately long and broad branchiostegal rays (Fig. 5A, B). A gular plate was not observed; it is probably absent as in other species of Lepidotes.

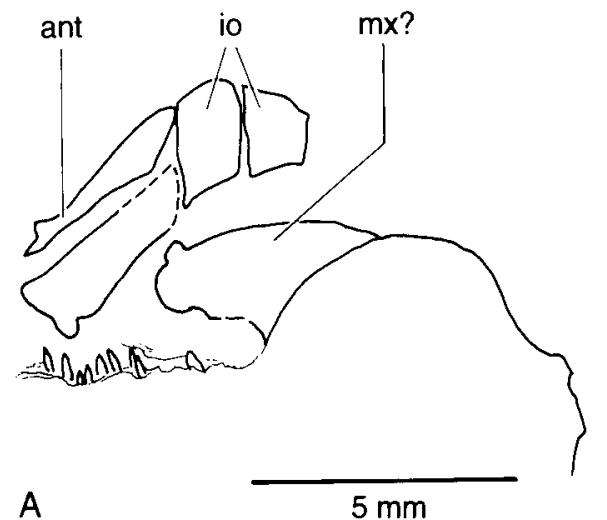

$5 \mathrm{~mm}$
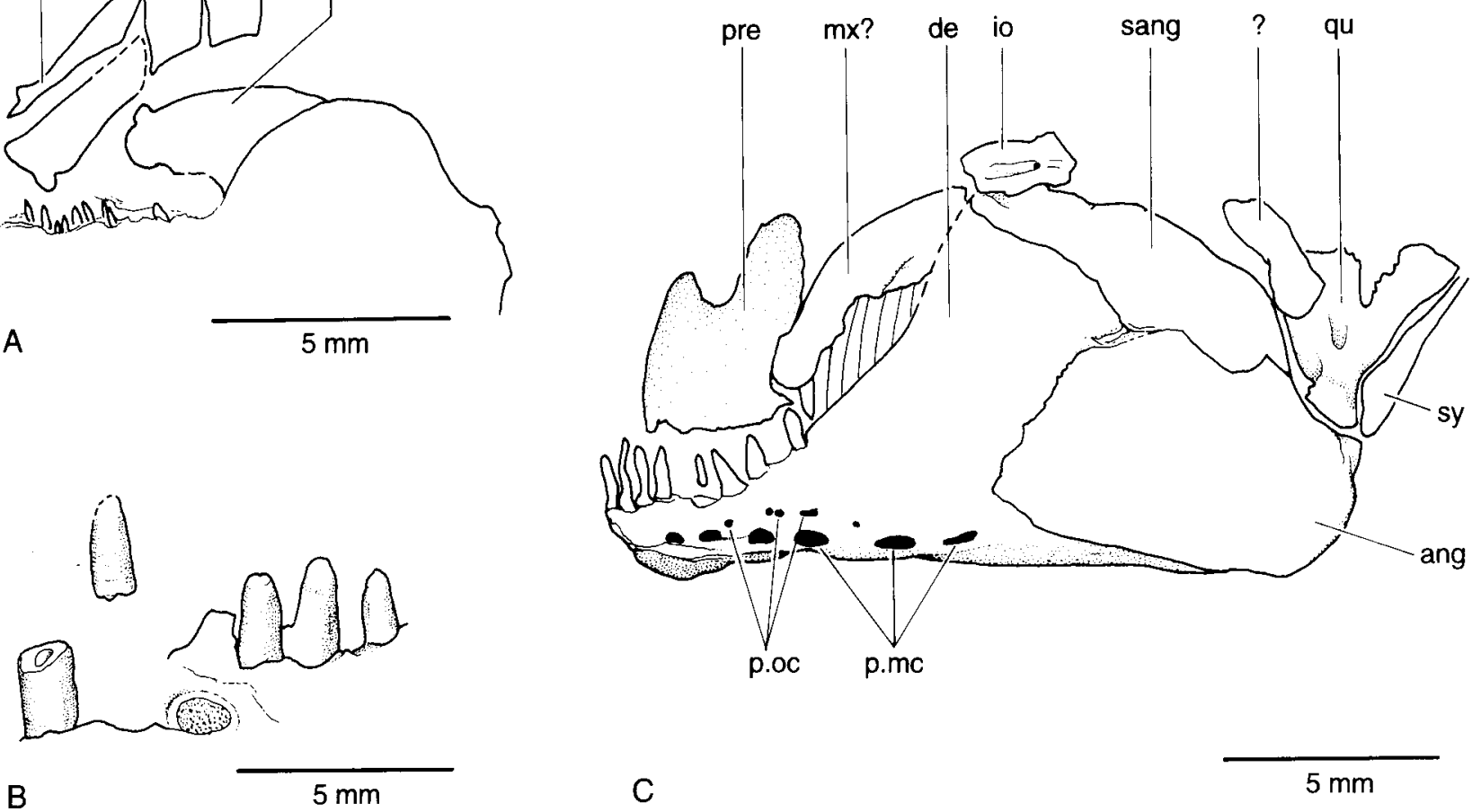

Fig. 10. Lepidotes tendaguruensis n. sp. A. Orbital bones and part of lower jaw (MB. f.7048). B. Detail of dentalosplenial teeth (MB. f.7048). C. Upper and lower jaws in lateral view (MB. f.7043). Obere Sauriermergel, Tithonian, Upper Jurassic/Locality M, approximately $250 \mathrm{~m}$ south of Tendaguru Hill, Tendaguru, Tanzania. ant, antorbital?; de, dentalosplenial; io, infraorbital bone; mx?, maxillary bone?; p.mc, pores of the mandibular canal; p.oc, pores of the oral canal; pre, premaxilla; qu, quadrate; sang, surangular; sy, symplectic 
Bones of the branchial arches are scattered in all specimens, incompletely preserved and disarticulated. They are small, and we have not seen teeth or tooth plates associated with them.

The opercular region includes the preoperculum, operculum, suboperculum, and interoperculum; the bones appear to lack any ornamentation. The preoperculum (Figs $4,5 \mathrm{~A}, 7 \mathrm{~A}, \mathrm{~B}$ ) is narrow, shallowly curved, and almost vertical. Its dorsal portion does not reach the neurocranium, therefore the dorsal part of the hyomandibula is exposed in the specimens. The preoperculum produces a narrow anterior lamina were the suborbital 2 lies. The preopercular canal is usually preserved as a groove; however, it is unclear whether this is an artifact of preservation or if a thin layer of bone covered the canal. The operculum (Figs 4, 5A, 7A, B, 8B) is deeper than wide, with a slightly convex posterior margin. The suboperculum (Figs 4, 7A, B, 8B) is relatively small; it is about one quarter the depth of the operculum. The bone is characterized by an extremely long and massive dorsal process which has the same depth as the body of the suboperculum. It extends between the anterior margin of the operculum and the posterior margin of the preoperculum. A series of pits runs close to the ventral margin of the bone and they are interpreted here as pits for the subopercular neuromast line. The interoperculum, in the usual position below the preoperculum, is incompletely preserved in all specimens.

Bones of the pectoral girdle are usually covered by the operculum or by scales. Still, the supracleithrum, cleithrum, and postcleithra are visible. The supracleithrum (Figs 5A, 8A, B) is a narrow elongated bone bearing the lateral line. The cleithrum is heavily ossified, but it is incomplete in all specimens. It is a long and arched bone, narrow at its dorsal region and considerably expanded ventrally. Ossified ridges bearing denticles have not been observed in medial view of the available material; it is possible that these are not formed yet in the juvenile specimens. Two postcleithra (Fig. 8A) are present. The dorsal postcleithrum or postcleithrum 1 is a long element placed behind the cleithrum; the ventral postcleithrum, although incomplete, is considerably smaller than the dorsal one.

Thirteen pectoral fin-rays are preserved in the holotype (Hennig 1914 reported 11). In our postjuvenile specimens, the rays have long bases and are distally finely segmented and branched. All other fins are incompletely preserved or disarticulated. Fringing fulcra and scutes are not as- sociated with any fin, not even they are present as disarticulated elements; however, a basal fulcrum has been observed associated with an isolated portion of a caudal fin.

The scales have a smooth ganoin surface and a straight posterior margin. The processes at the anterodorsal and anteroventral corners are very pronounced; they are larger than the peg at the dorsal margin (MB. f.4049; Hennig 1914: fig. 1).
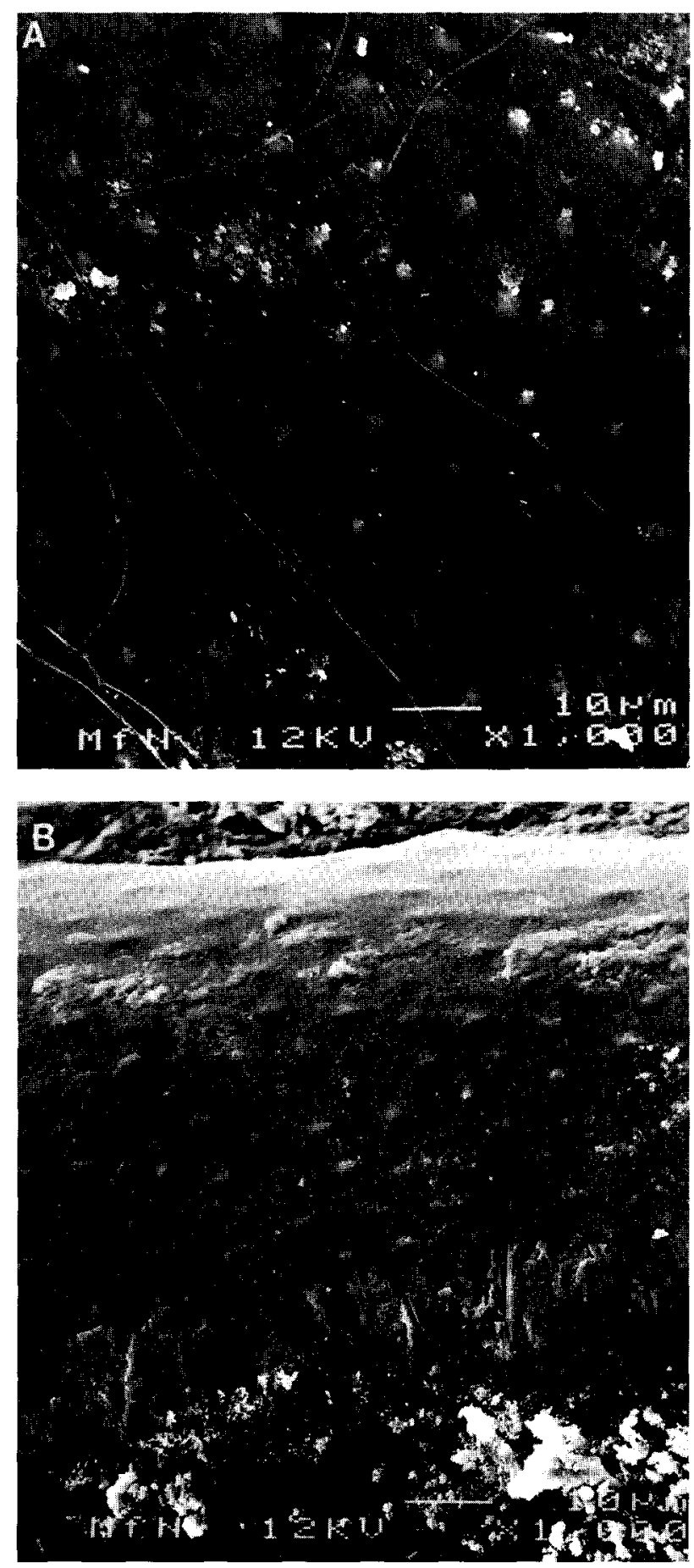

Fig. 11. Lepidotes tendaguruensis n. sp., tubercles on the ganoin surface. A. Scale. B. Lepidotrichium. Obere Sauriermergel, Tithonian, Upper Jurassic/Locality M, approximately $250 \mathrm{~m}$ south of Tendaguru Hill, Tendaguru, Tanzania 


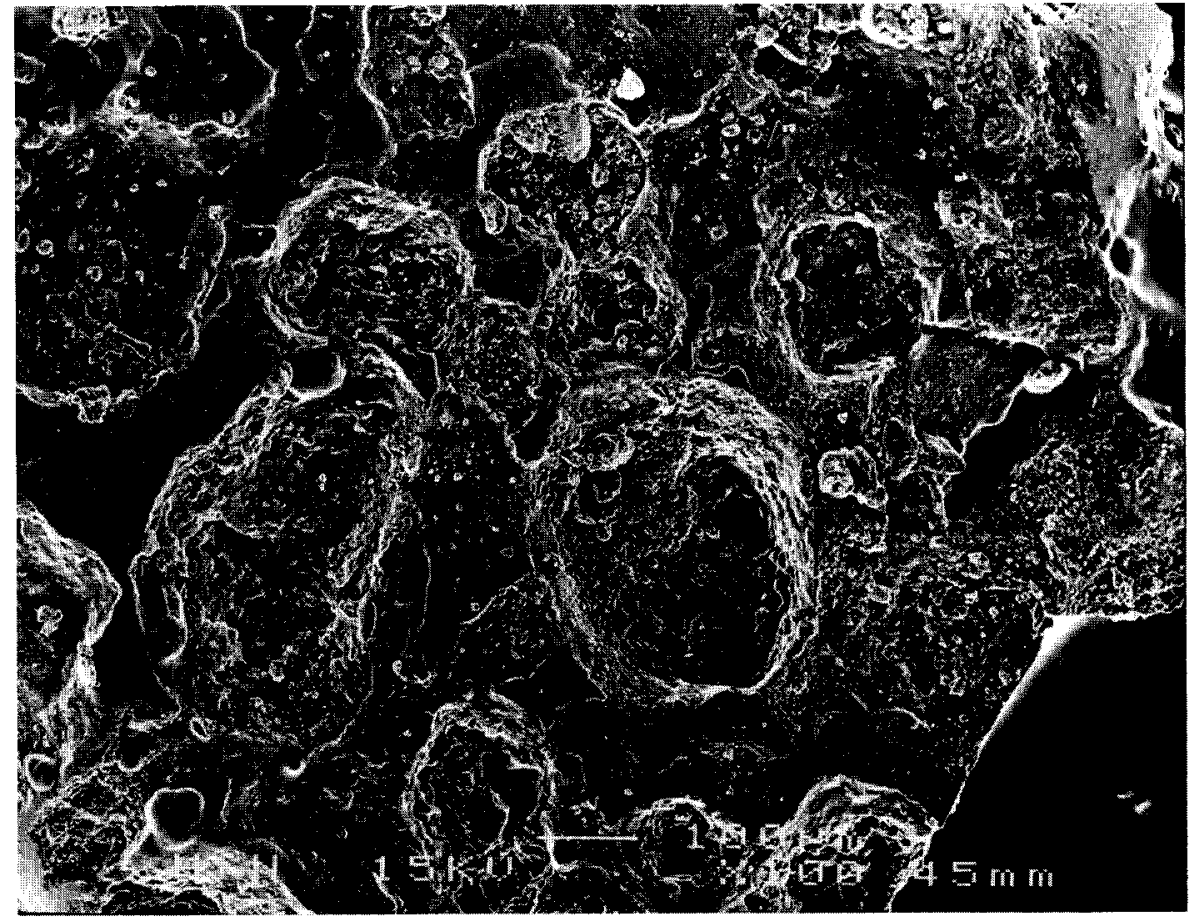

Fig. 12. Lepidotes tendaguruensis n. sp., resorption pits in the ganoin of one scale $(\times 350)$. Obere Sauriermergel, Tithonian, Upper Jurassic/Locality M, approximately $250 \mathrm{~m}$ south of Tendaguru Hill, Tendaguru, Tanzania
The ganoin surface shows the typical ganoin tuberculation under high magnification (Fig. 10A) as described by Schultze (1966, 1977), Ørvig (1967), and Gayet \& Meunier (1986). The tuberculation is specific for species and genera after Gayet \& Meunier (1986) and Meunier \& Gayet $(1992,1996)$. The distance between the tubercles varies between 5.5 and $8.4 \mu \mathrm{m}$, and the diameter between 1.9 and $4.0 \mu \mathrm{m}$ on the ganoin surface of one scale of $L$. tendaguruensis (Fig. $11 \mathrm{~A}$ ). The measurements are quite different on a lepidotrichium (Fig. 11B) with 4.3 to $5.5 \mu \mathrm{m}$ distances in between and 1.8 to $3.3 \mu \mathrm{m}$ diameter of the tubercles. None of the measurements corresponds to Lepidotes (sensu Meunier \& Gayet 1992), and the variation does not indicate species specificity. The ganoin surface of most scales in locality $M$ shows many deep resorption pits (Fig. 12). Comparable structures have been shown in the Late Cretaceous/Early Paleogene semionotid, Lepidotyle enigmatica, from Bolivia by Meunier \& Gayet (1992). Meunier \& Gayet (1992) interpreted the feature as an indication of the fresh water influence which dissolved the calcium. For marginal marine taxa like Lepidotyle and Lepidotes, the phenomenon could be explained as a migration of the fish into fresh water (during reproduction) or as influx of fresh water from rivers.

\section{Comparison and discussion}

The Semionotidae sensu Olsen \& McCune (1991) form a monophyletic group on the basis of two synapomorphies: the presence of dorsal ridge scales with a posterodorsal spine, and a single anamestic suborbital. Olsen \& McCune (1991) included only two genera, Semionotus and Lepidotes, within the family. Tintori (1996) showed that Paralepidotus is also a member of the family, as are the Cretaceous genera Araripelepidotes (Maisey 1991) and Pliodetes (Wenz 1999). Wenz (1999) divided the Semionotidae in three groups, Semionotus + Paralepidotus with a single anamestic suborbital, a second group with Araripelepidotes + some Lepidotes species with $2-10$ suborbitals in one row, and a third group with Pliodetes + other Lepidotes species with a mosaic of suborbitals. The first group possesses generalized actinopterygian characters like the presence of three bones (dentalosplenial, surangular, and angular) in the lateral side of the lower jaw and a high coronoid process. In contrast, Araripelepidotes and Pliodetes have only two bones (dentalosplenial and angular) in the lateral side of the lower jaw and no coronoid process. L. tendaguruensis belongs to the Lepidotes species of the second group; it shares with the group two suborbitals, and with Lepidotes the possession of a surangular in contrast to Araripelepidotes and Pliodetes.

Lepidotes tendaguruensis $\mathrm{n}$. $\mathrm{sp}$. shares with other members of the Semionotiformes sensu Ol- 
sen \& McCune (1991: including Semionotidae, Macrosemiidae, and Lepisosteidae) the presence of an epiotic with a posterior process bearing projections. A posterior process with projections is not unique to the Semionotiformes, the feature is found in a variety of fishes like pycnodontiforms (Nursall 1996, 1999) and teleosts such as Varasichthys (Arratia 1981) and gonorynchiforms. In Lepidotes toombsi, the epiotic has a strong, thick and heavily ossified posterior projection which ends in numerous short dentations (Patterson 1975: fig. 111). Nevertheless, a broad flat posterior process of the epiotic with few short tooth-like dentations (Figs 4, 8A) is an autapomorphy of $L$. tendaguruensis $\mathbf{n}$. $\mathrm{sp}$.

The presence of only two extrascapular bones meeting each other in the midline seems to be the generalized pattern in many neopterygians. For instance, two extrascapular bones are present in Parasemionotiformes, Ionoscopiformes, Amiiformes other than Sinamiidae with six (Grande \& Bemis 1998), in Semionotidae (Olsen \& McCune 1991, Tintori 1996) except for Dapedium with 10 (Patterson 1973), and in primitive teleosts except for some advanced ones (Arratia 1997, 1999). The primitive pattern is found in Early Jurassic Lepidotes such as $L$. elvensis (Wenz 1968, Thies 1989b), L. leedsi, L. notopterus, $L$. deccanensis, and in juvenile forms of $L$. tendaguruensis $\mathrm{n}$. sp. and the Cenomanian L. temnurus from Brazil (Erasmo 1938). Exceptions are Late Jurassic and Cretaceous species of Lepidotes (Wagner 1863, Woodward 1893, 1895, Weitzel 1930, Jain 1983) with four extrascapular bones (e.g., Lepidotes maximus: Jain \& Robinson 1963; Lepidotes sp.: Thies \& Zapp 1997) and the genera Araripelepidotes (Maisey 1991: 122) and Pliodetes (Wenz 1999). Six or more extrascapular bones are present in Lepidotes laevis and L. pustulosus. Four to six extrascapular bones are present in Lepisosteiformes. Among neopterygians, special conditions are found in Macrosemiiformes and Pycnodontiformes. Due to the variation found in some groups, the number of extrascapular bones needs to be further investigated in numerous neopterygians, because it can be an apomorphic character at certain phylogenetic levels, or an autapomorphy of some species.

The lateral portion of the most external extrascapula in Lepidotes has usually been restored broader than the mesial part, triangular in shape. However, the extrascapula of $L$. tendaguruensis $\mathrm{n}$. sp. is L-shaped with the lateral portion resting on the dermopterotic where the otic canal penetrates the bone.
The first synapomorphy of the Semionotidae, a posterodorsal spine on the dorsal ridge scales, is not present in the new species as well as in numerous species of Lepidotes (Thies 1989a). According to McCune $(1986,1987)$ a series of simple, convex scales with moderate to well developed spines along the dorsal midline between the extrascapular bones and the origin of the dorsal fin is present in Semionotus and Lepidotes. In Lepidotes a series of scales with a dorsal spine is found in $L$. minor, $L$. deccanensis, and $L$. maximus among others. The scales are inconspicuous, more or less pointed but without a posterior spine like in the type species $L$. elvensis (Quenstedt 1847, Wenz 1968). We interpret the absence of a posterodorsal spine on the dorsal ridge scales as the primitive condition in Semionotidae by comparison with possible outgroups such as the parasemionotids, pycnodontiforms, lepisosteids, amiiforms, and other neopterygians. Therefore, the presence or absence of the feature can be used as a character in determining phylogenetic relationships of species within the genus.

Semionotidae may have one (Semionotus, Paralepidotus) or more than one suborbital bone (Lepidotes, Araripelepidotus, Pliodetes). It is well known that the suborbital bones are variable intraspecifically, and even between left and right sides of an individual. Despite such variation, the species of Lepidotes might be separated into two groups, one with three to six plates distributed in a single row, and another with seven or more suborbitals in one or more rows (Jain \& Robinson 1963). According to these authors, two suborbitals are occasionally present in Lepidotes minor. L. tendaguruensis n. sp. presents two suborbital bones in all individuals in which the cheek is preserved; therefore the pattern is the common one for the new species. The shape of the two suborbitals is similar in $L$. minor and L. tendaguruensis $\mathrm{n}$. sp.; however, both species differ in other features of the circumorbital series.

In Lepidotes the infraorbital series is commonly composed of slightly square or rectangular, small bones of similar size. In contrast, the infraorbital at the posteroventral corner of the orbit of L. tendaguruensis $\mathrm{n}$. sp. is enlarged and slightly expanded posteroventrally.

Two or five infraorbital (or antorbital) bones reach in front of the orbit in Lepidotes. Four infraorbitals or antorbitals are present in that position in L. tendaguruensis $\mathrm{n}$. sp. The presence of four bones is unique among semionotiforms, and in addition, the rectangular shape of infraorbitals 
1 and 2 (antorbitals?) and their position above each other is also a unique feature.

In Recent fishes neuromasts can be distributed in neuromast fields or lines. Neuromast lines may consist of single neuromasts located at the bottom of shallow pits (pit-lines), in grooves of the epidermis (grooves lines) or enclosed in canals (canal lines) (Coombs et al. 1988, Northcutt 1989, Arratia \& Huaquín 1995). Small pits on the surface of head bones of some fossils have been interpreted as pits for neuromasts. For instance, in Lepidotes sp. there are fields of neuromasts in several head bones such as parietal, postparietal, circumorbital and opercular bones (Thies \& Zapp 1997: fig. 7). In contrast, the neuromast pits in the new species from Tendaguru are distributed in lines (e.g., parietal line, subopercular line) and are scarce or absent in the operculum. The comparison is limited due to missing information for most species of Lepidotes, and that the development of neuromasts shows ontogenetic variation in Recent fishes (Coombs et al. 1988, Arratia \& Huaquín 1995).

The dentalosplenial, as well as all other bones bearing dentition, has non-tritoral teeth in Lepidotes tendaguruensis $\mathrm{n}$. $\mathrm{sp}$. The non-tritoral condition is shared with other species such as L. elvensis, L. deccanensis (Jain 1983), and L. gallineki (Michael 1893). In contrast, L. minor has moderately tritoral teeth on the lateral margins of coronoid bones and bones of the palate, and the medial teeth are tritoral. Like in other nontritoral species, the new species has a shallow and anteriorly slender dentalosplenial with a narrow symphysis.

The hyomandibula of Lepidotes tendaguruensis $\mathrm{n}$. sp. expands anteriad due to the presence of a well developed membranous outgrowth. This feature differs from the condition in L. minor and $L$. mantelli with a slightly expanded hyomandibula (Woodward 1919, Gardiner 1960) and L. semiserratus, L. latifrons (Woodward 1893, Rayner 1948), L. congolensis (Saint-Seine 1950), and L. gloriae (Thies 1989a) with a narrow hyomandibula lacking the membranous outgrowth. According to the available information, the presence of an enlarged membranous outgrowth is an autapomorphy of L. tendaguruensis $\mathrm{n}$. sp. In addition, the new species presents a remarkable feature, an articular surface on the membranous outgrowth. We interpret the articulation as one with the basipterygoid process.

The metapterygoid (Figs 7A, 8B) of Lepidotes tendaguruensis $\mathrm{n}$. $\mathrm{sp}$. is a large chondral bone which even in large specimens keeps a consider- able quantity of cartilage or transforming cartilage. We suppose that the metapterygoid has enlarged its size considerably to compensate the small size of the quadrate, and therefore, being an important element of the suspensorium of the lower jaw.

The total number of branchiostegal rays in Lepidotes tendaguruensis $\mathrm{n}$. sp. is unknown. Six rays are preserved in one specimen (Fig. 5B) but one or more appear to be missing. Apparently, species of Lepidotes have few branchiostegal rays, e.g., six or seven are reported from L. mantelli and L. lennieri (Woodward 1919, Wenz 1968) and five are preserved in L. elvensis (Thies 1989b).

The preoperculum (Figs 4, 5A, B, 7A, B) of Lepidotes tendaguruensis $\mathrm{n}$. sp. is weakly curved, almost vertical like in other species of Lepidotes. However, it differs from other species in that the dorsal portion of the bone is short; consequently, the preoperculum does not reach the dermopterotic and the dorsal portion of the hyomandibula is exposed laterally.

The operculum (Figs 4, 5A, B, 7A, B) of Lepidotes tendaguruensis $\mathrm{n}$. $\mathrm{sp}$. has straight anterior and ventral margins. The dorsal and posterior margins are slightly convex. The depth of the operculum is approximately equal to its maximum length. This feature disagrees with the general pattern in Lepidotes with an operculum deeper than long.

The pectoral girdle is incompletely known in numerous species of Lepidotes. Three postcleithra have been reported for $L$. minor and Lepidotes sp. (Thies \& Zapp 1997; compare to Watsonulus in Grande \& Bemis 1998: fig. 415) and four for L. mantelli (Woodward 1919). L. tendaguruensis n. sp. presents only two postcleithra (Fig. 8A) as described in other neopterygians such as Ophiopsis, Ionoscopus (Grande \& Bemis 1998: fig. 410) and Atacamichthys (Arratia \& Schultze 1987: figs 13A, 19). The dorsal postcleithrum (Fig. 8A) is a large bone that contacts dorsally with the supracleithrum, whereas the ventral one is small and broad. Apparently, the feature can be diagnostic for the new species, but more information on other species of the genus is needed.

The genus Lepidotes (as well as other Semionotidae and other primitive neopterygians) has fringing fulcra on all fins. In contrast, $L$. tendaguruensis $\mathrm{n}$. sp. lacks fringing fulcra on all fins, a feature that we interpret as an autapomorphy of the new species. In addition, we have not observed basal fulcra associated with the dorsal fin in the new species, but only with the caudal fin. 
The scales of Lepidotes tendaguruensis $\mathrm{n}$. $\mathrm{sp}$. have a smooth surface and a straight posterior margin (Hennig 1914). The anterodorsal corner forms a long projection, larger than the dorsal peg. The anteroventral corner projects not as much. The ganoin surface shows the typical minute tuberculation (Fig. 11A, B) which does not show distances or diameter of the tubercles typical for Lepidotes as supposed by Meunier \& Gayet (1992).

\section{Lepidotes minor and L. tendaguruensis n. sp.}

Based on the number of scale rows, Hennig (1914) assigned the specimens of Tendaguru to Lepidotes minor, a species described by Agassiz (1832) from the Purbeckian of England. In addition to similar scale counts, both species are also similar in the presence of two suborbitals (commonly three in L. minor). Despite these similarities, numerous features separate both species. For instance: (1) The proportions of cranial bones: The postparietal is a large bone in $L . ~ m i-$ nor, it is approximately one third of the length of the parietal (Woodward 1895). In contrast the bone is smaller in L. tendaguruensis $\mathrm{n}$. $\mathrm{sp}$. where it is only approximately a quarter of the parietal. (2) The bones of the skull roof are densely ornamented in $L$. minor, whereas scattered tubercles occur in the new species. (3) Lepidotes minor has moderately tritoral teeth, whereas the new species is non-tritoral. (4) Infraorbital bone at the posteroventral corner of the orbit is slightly expanded posteroventrally in the new species; it is not expanded in L. minor. (5) Three infraorbital or antorbital bones anterior to the orbit are present in $L$. minor, four in the new species. (6) The preoperculum is a deep bone in L. minor, it reaches the lateral side of the dermopterotic; it is short in the new species. (7) The hyomandibula is expanded throughout with a well developed membranous outgrowth in L. tendaguruensis n. sp.; such an outgrowth is missing in L. minor. (8) Three postcleithra are present in L. minor, whereas the new species has only two. (9) Fringing fulcra are present on all fins of $L$. minor. They are absent in the new species.

\section{Conclusions}

The specimens from the Upper Jurassic of Tendaguru present a combination of features that is unique within the genus Lepidotes and that justifies the creation of a new species. For instance, the presence of scattered tubercles on cranial bones of adults, smooth ganoid scales, broad posterior process of the epiotic ending in a few tooth-like dentations, two suborbital bones, one row of infraorbital bones, non-tritoral teeth, hyomandibula with an anteriorly expanded membranous outgrowth, two extrascapular bones, two postcleithra, and the absence of fringing fulcra on all fins.

According to morphological evidence, the new species questionably belongs in the second group of the Semionotidae that includes some species of Lepidotes and Araripelepidotes (sensu Wenz 1999). It shares with the group two suborbital bones, and the possession of a surangular with Lepidotes, in contrast to Araripelepidotes (member of the second group) and Pliodetes (member of the third group). This conflict of features requires a revision of the whole group to clarify its content and its phylogenetic relationships.

\section{Acknowledgements}

The authors thank Mr. L. Berner for the preparations of specimens MB. f.7040 and MB. f.7041 (other specimens were prepared by G. Arratia), Mrs. W. Harre for the photographs, and Mr. J.-P. Mendau for the illustrations based on the original drawings by G. Arratia. Dr. E. Wäsch was very helpful with the SEM photographs and Dr. W.-D. Heinrich kindly supplied the locality data. Our special thanks to Drs. Daniel Goujet and Lance Grande for reviewing the manuscript.

\section{References}

Agassiz, L. 1832. Untersuchungen über die fossilen Fische der Lias-Formation. - Neues Jahrbuch für Mineralogie, Geognosie, Geologie und Petrefaktenkunde 3: 139-149.

- 1833-44. Recherches sur les Poissons Fossiles. 5 vols., 1420 pp., with supplements, Petitpierre, Neuchâtel et Soleure.

Arambourg, C. \& Bertin, L. 1958. Super-Ordres des Holostéens et des Halécostomes (Holostei et Halecostomi). In Grassé, P. (ed.). Traité de Zoologie 13 (3): 2173-2203, Masson et Cie., Paris.

Arratia, G. 1981. Varasichthys ariasi n. gen. et sp. from the Upper Jurassic of Chile (Pisces, Teleostei, Varasichthyidae n. fam.). - Palaeontographica, Abteilung A 175: 107-139.

- 1997. Basal teleosts and teleostean phylogeny. - Palaeo Ichthyologica 7: 5-168.

- 1999. The monophyly of Teleostei and stem-group teleosts. Consensus and disagreements. In Arratia, G. \& Schultze, H.-P. (eds.). Mesozoic Fishes 2 - Systematics and Fossil Record: 265-334, Verlag Dr. F. Pfeil, München.

Arratia, G. \& Cione, A. L. 1996. The record of fossil fishes of southern South America. In Arratia, G. (ed.). Contributions of Southern South America to Vertebrate Paleontology. - Münchner Geowissenschaftliche Abhandlungen 30: $9-72$.

Arratia, G. \& Cloutier, R. 1996. Reassessment of the morphology of Cheirolepis canadensis (Actinopterygii). In Schultze, H.-P. \& Cloutier, R. (eds.). Devonian Fishes and Plants of Miguasha, Quebec, Canada: 165-197, Verlag Dr. Pfeil, München. 
Arratia, G. \& Huaquín, L. 1995. Morphology of the lateral line system and of the skin of diplomystid and certain primitive loricarioid catfishes and systematic and ecological considerations. - Bonner Zoologische Monographien 36: $1-110$.

Arratia, G. \& Schultze, H.-P. 1987. A new halecostome fish (Actinopterygii, Osteichthyes) from the Late Jurassic of Chile and its relationships. - Dakoterra 3: 1-13, Rapid City, South Dakota.

- 1990. The urohyal: Development and homology within osteichthyans. - Journal of Morphology 203: 247-282.

- 1991. Palatoquadrate and its ossifications: Development and homology within osteichthyans. - Journal of Morphology 208: $1-81$.

Blainville, H. D. de 1818. Poissons fossiles. Nouvelle Dictionaire d'Histoire Naturelle. Nouvelle édition, Vol. 27, Paris.

Bocchino, A. 1973. Semionotidae (Pisces, Holostei, Semionotiformes) de la Formación Lagarcito (Jurásico superior?), San Luis, Argentina. - Ameghiniana 10: 254-268.

Borgen, U. J. 1983. Homologization of skull roofing bones between tetrapods and osteolepiform fishes. - Palaeontology 26: $735-753$.

Branco, W. 1887. Beitäge zur Kenntniss der Gattung Lepidotus. - Abhandlungen zur geologischen Specialkarte von Preussen und den Thüringischen Staaten 7: 317-407.

Chang, M.-m. \& Jin, F. 1996. Mesozoic fish faunas of China In Arratia, G. \& Viohl, G. (eds.). Mesozoic Fishes - Systematics and Paleoecology: 461-478, Verlag Dr. F. Pfeil, München.

Coombs, S., Janssen, J. \& Webb, J. F. 1988. Diversity of the lateral line systems: evolutionary and functional considerations. In Atema, J., Fay, R. R., Popper, A. N. \& Tavolga, W. N. (eds.). Sensory Biology of Aquatic Animals: 553-593, Springer, New York, Berlin, Heidelberg.

Dechaseaux, C. 1943. Contribution à l'étude du genre Lepidotus. - Annales de Paléontologie 30: 3-13.

Erasmo, G. d' 1938. Ittioliti cretacei del Bresile. - Atti dell'Accademia delle Scienze fisiche e matematiche, Napoli 1, serie 2: 1-44.

Egerton, P. M. G. 1878. On some remains of ganoid fishes from the Deccan. - Palaeontologica Indica 1 (2): 1-8.

Gardiner, B. G. 1960. A revision of certain actinopterygian and coelacanth fishes, chiefly from the Lower Lias. Bulletin of the British Museum (Natural History), Geology 4: 241-384.

Gardiner, B. G. \& Schaeffer, B. (1989): Interrelationships of lower actinopterygian fishes. - Zoological Journal of the Linnean Society of London 97: 135-187.

Gayet, M. \& Meunier, F. J. 1986. Apport de l'étude de l'ornementation microscopique de la ganoïne dans la détermination de l'appartenance générique et/ou spécifique d'écailles isolées chez les Actinoptérygiens. - Comptes Rendus de l'Académie des Sciences 303, série 2: $1259-1262$.

Grande, L. \& Bemis, W. 1998. A comprehensive phylogenetic study of amiid fishes (Amiidae) based on comparative skeletal anatomy. An empirical search for interconnected patterns of natural history. - Journal of Vertebrate Paleontology 18, supplement 1, Memoir 4: $1-690$.

Hennig, E. 1914. Die Fischreste unter den Funden der Tendaguru-Expedition. - Archiv für Biontologie III (4): 293-312, $1 \mathrm{pl}$.

Heinrich, W.-D. 1999. The taphonomy of dinosaurs from the Upper Jurassic of Tendaguru, Tanzania, East Africa. Mitteilungen aus dem Museum für Naturkunde in Berlin, Geowissenschaftliche Reihe 2: 25-61.

Jain, S. L. 1983. A review of the genus Lepidotes (Actinopterygii: Semionotiformes) with special reference to the species from the Kota Formation (Lower Jurassic), India. - Journal of the Paleontological Society of India 28 $7-42$.
- 1985. Some new observations on Lepidotus maximus (Holostei: Semionotiformes) from the German Upper Jurassic. - Journal of the Palacontological Society of India 30: $18-25$.

Jain, S. L. \& Robinson. P. L. 1963. Some new specimens of the fossil fish Lepidotes from the English Upper Jurassic. - Proceedings of the Zoological Society of London 141: 119-135.

Jollie, M. 1962. Chordate Morphology. XIV + 478 pp., Reinhold Books, New York.

Lehman, J.-P. 1966. Actinopterygii. In Piveteau, J. (ed.). Traité de Paléontologie IV (3): 1-242, Masson et Cie. Paris.

Long, J. A. 1988. New palaeoniscoid fishes from the Late Devonian and Early Carboniferous of Victoria. - Memoirs of the Association of Australasian Palaeontologists 5 , 7: $1-64$.

Maisey, J. 1991. Santana Fossils. An illustrated Atlas. 459 pp., T.F.H. Publications, Inc., Neptune, New Jersey.

Malzahn, E. 1963. Beiträge zur Geschiebeforschung (4. Beitrag). Lepidotus elvensis Blainville aus dem Posidonienschiefer der Dobbertiner Liasscholle, mit speziellen Untersuchungen zur Histologie des Operculums. - Geologisches Jahrbuch 80: 539-560.

Mann, O. \& Hennig, E. 1913. Mesozoische Ablagerungen in Adamaua, Kamerun. - Beiträge zur geologischen Erforschung der Deutschen Schutzgebiete Heft 7: 10-29.

McCune, A. R. 1986. A revision of Semionotus (Pisces: Semionotidae) from the Triassic and Jurassic of Europe. - Palaeontology 170: 213-531.

- 1987. Toward the phylogeny of a fossil species flock: Semionotid fishes from a lake deposit in the Early Jurassic Towaco Formation, Newark Basin. - Bulletin of Yale University Peabody Museum of Natural History 43: $1-108$.

Meunier, F. J. \& Gayet, M. 1992. Remaniement de la ganoïne chez un semionotidae nouveau du Crétacé supérieur de Bolivie: Intérêt paléobiologique. - Geobios 25 (6): $767-774$.

1996. A new polypteriform from the Late Cretaceous and the middle Paleocene of South America. In Arratia, G. \& Viohl, G. (eds.). Mesozoic Fishes - Systematics and Paleoecology: 95-103, Verlag Dr. F. Pfeil, München.

Michael, R. 1893. Über eine neue Lepidosteiden-Gattung aus dem oberen Keuper Oberschlesiens. - Zeitschrift der Deutschen geologischen Gesellschaft XLV: 710-729.

Northcutt, G. 1989. The phylogenetic distribution and innervation of craniate mechanoreceptive lateral lines. In Coombs, S. P., Görner, P. \& Münz, H. (eds.). The Mechanosensory Lateral Line: 17-78, Springer, New York.

Nursall, J. R. 1996. The phylogeny of pycnodont fishes. In Arratia, G. \& Viohl, G. (eds.). Mesozoic Fishes - Systematics and Paleoecology: 125-152, Verlag Dr. F. Pfeil, München.

- 1999. The family †Mesturidae and the skull of pycnodont fishes. In Arratia, G. \& Schultze, H.-P. (eds.). Mesozoic Fishes 2 - Systematics and Fossil Record: 153-188, Verlag Dr. F. Pfeil, München.

Ørvig, T. 1967. Phylogeny of tooth tissues: evolution of some calcified tissues in early vertebrates. In Miles, A. E. W. (ed.). Structural and chemical organization of teeth. Vol. 1: 45-105, Academic Press, New York.

Olsen, P. E. \& McCune, A. R. 1991. Morphology of the Semionotus elegans species group from the Early Jurassic part of the Newark Supergroup of Eastern North America with comments on the family Semionotidae (Neopterygii). - Journal of Vertebrate Paleontology 11: 269-292.

Patterson, C. 1973. Interrelationships of holosteans. In Greenwood, P. H., Miles, R. S. \& Patterson, C. (eds.). Interrelationships of Fishes. - Zoological Journal of the Linnean Society, London 53, Supplement 1: 233-305, Academic Press, London. 
- 1975. The braincase of pholidophorid and leptolepid fishes, with a review of the actinopterygian braincase. Philosophical Transactions of the Royal Society of London, Series B 269: 275-579.

Priem, F. 1908. Étude sur le genre Lepidotus. - Annales de Paléontologie 3: 1-19.

Quenstedt, F. A. 1847. Anzeige der akademischen Feier des Geburtsfestes Seiner Majestät des Königs Wilhelm von Württemberg im Namen des Rektors und des Senats der königlichen Eberhard-Karls-Universität zu Tübingen, nebst Lepidotus im Lias Epsilon Württembergs. 18 pp., L. F. Fues, Tübingen.

Rayner, D. H. 1948. On the cranial structures of certain holostean fishes, with special reference to their neurocrania. - Philosophical Transactions of the Royal Society London, Series B, Biological Sciences 233: 287-345.

Regan, C. T. 1923. The skeleton of Lepidosteus, with remarks on the origin and evolution of the lower neopterygian fishes. - Proceedings of the Zoological Society of London 1923: 445-461.

Romer, A. S. 1945. Vertebrate Paleontology. 2nd. ed.: viii + 468, The University of Chicago Press, Chicago and London.

Saint-Seine, P. de. 1949. Les poissons des calcaires lithographiques de Cerin (Ain). - Nouvelle Archive, Muséum d'Histoire naturelle, Lyon 2: 1-257.

- 1950. Contribution à l'étude des vertébrés fossiles du Congo Belge. - Annales du Musée du Congo Belge, Série 8, Sciences Géologiques 5: 5-32.

Sauvage, M. H.-E. 1893. Description de deux espèces nouvelles du poissons de terrain kimméridgien du Cap de la Hève. - Bulletin, Société Géologique de la Normandie 14: $3-7$.

Schultze, H.-P. 1966. Morphologische und histologische Untersuchungen an den Schuppen mesozoischer Actinopterygier (Übergang von Ganoid- zu Rundschuppen). Neues Jahrbuch für Geologie und Paläontologie, Abhandlungen 126: 232-314.

- 1977. Ausgangsform und Entwicklung der rhombischen Schuppen der Osteichthyes (Pisces). - Paläontologische Zeitschrift 51: $152-168$.

- 1993. Patterns of diversity in the skulls of jawed fishes. In Hanken, J. \& Hall, B. K. (eds.). The Skull. Volume 2. Patterns of Structural and Systematic Diversity: 189-254, The University of Chicago Press, Chicago and London.

- 1996. The scales of Mesozoic actinopterygians. In Arratia, G. \& Viohl, G. (eds.). Mesozoic Fishes - Systematics and Paleoecology: 243-259, Verlag Dr. F. Pfeil, München.

Schultze, H.-P. \& Arsenault, M. 1985. The panderichthyid fish Elpistostege: A close relative of tetrapods? - Palaeontology 28: 293-309.

Schultze, H.-P. \& Wiley, E.O. 1984. The neopterygian Amia as a living fossil. In Eldredge, N. \& Stanley, S. M. (eds.). Living Fossils: 153-159, Springer Verlag, New York.

Silva Santos, R. da. 1953. Lepidotídeos do Cretáceo da ilha de Itaparica, Estado de Bahia. - Ministério de Agricultura, Departamento Nacional da Produçao Mineral, Divisão de Geologia e Mineralogia, Boletim 145: 1-23.
Thies, D. 1988. Dapedium pholidotum (Agassiz, 1832)? (Pisces, Actinopterygii) aus dem Unter-Toarcium NWDeutschlands. - Geologica et Palaeontologica 22: $89-212$.

- 1989a. Lepidotes gloriae, sp. nov. (Actinopterygii: Semionotiformes) from the Late Jurassic of Cuba. - Journal of Vertebrate Paleontology 9 (1): 18-40.

- 1989b. Sinneslinien bei dem Knochenfisch Lepidotes elvensis (Blainville, 1818) (Actinopterygii, $\nmid$ Semionotiformes) aus dem Oberlias (Unter-Toarcium) von Grimmen in der DDR. - Neues Jahrbuch für Geologie und Paläontologie, Monatshefte 1989 (11): 692-704.

Thies, D. \& Zapp, M. 1997. Ein Lepidotes (Actinopterygii, $\dagger$ Semionotiformes) aus den Plattenkalken (Oberjura, oberes Kimmeridgium) bei Schamhaupten (Süddeutschland). - Archaeopteryx 15: 11-26.

Tintori, A. 1996. Paralepidotus ornatus (Agassiz 1833-43): A semionotid from the Norian (Late Triassic) of Europe. In Arratia, G. \& Viohl, G. (eds.), Mesozoic Fishes - Systematics and Paleoecology: 167-179, Verlag Dr. F. Pfeil, München.

Wagner, J. A. 1863. Monographie der fossilen Fische aus den lithographischen Schiefern Bayern's. Zweite Abtheilung. - Abhandlungen der königlich bayerischen Akademie der Wissenschaften, mathematisch-physikalische Klasse $\mathbf{9}$, 3: $612-748$.

Weitzel, K. 1930. Drei Riesenfische aus den Solnhofener Schiefern von Langenaltheim. - Abhandlungen der Senckenbergischen Naturforschenden Gesellschaft 42: 85-113.

Wenz, S. 1968. Compléments à l'étude des poissons actinoptérygiens du Jurassique français. - Cahiers de Paléontologie: 1-276; Paris (Centre National de Recherche Scientifique).

- 1999. Pliodetes nigeriensis, gen. nov., sp. nov., a new semionotid fish from the Lower Cretaceous of Gadoufaoua (Niger Republic): phylogenetic comments. In Arratia, G. \& Schultze, H.-P. (eds.). Mesozoic Fishes 2 - Systematics and Fossil Record: 107-120, Verlag Dr. F. Pfeil, München.

Wiley, E. O. 1976. The phylogeny and biogeography of fossil and Recent gars (Actinopterygii: Lepisosteidae). - Miscellaneous Publications of the University of Kansas 64: $1-111$.

Woodward, A. S. 1890. The fossil fishes of the Hawkesbury Series at Gosford. - Memoirs of the Geological Survey of New South Wales (Paleontological series) 4:1-56.

- 1893. On the cranial osteology of the Mesozoic ganoid fishes, Lepidotes and Dapedius. - Proceedings of the Zoological Society London 38: 559-565.

- 1895. Catalogue of the Fossil Fishes in the British Museum (Natural History). Part 3: 446-478 (Pholidophoridae), Trustees of the British Museum of Natural History, London.

- 1919. The fossil fishes of the English Wealden and Purbeck formations. - Palaeontographical Society, Monographs 71: $105-148$. 